\title{
Finding Norms for the Chinese Mission: The Hat Controversy in the Canton Conference of 1667/1668
}

\author{
Marina Torres Trimállez
}

\section{1 \\ Introduction}

In 1676, the Dominican friar Domingo Fernández de Navarrete (onward Navarrete), OP (1619-1689) showed his admiration for the Chinese empire by describing the beauty and mystery of the emperor's crown, 冕冠 mianguan. In his Tratados historicos, politicos, ethicos y religiosos de la monarchia de China, he claimed to have seen with his own eyes its round and tall shape in some temples. ${ }^{1}$ Navarrete explained that the quantity of tassels - a total of 12 pearls dangled from the crown-marked the emperor's status as 天子 tianzi-Son of Heaven - and he described their symbolism thus:

Four of them over the eyes, which signify that the Emperor's eyes must be shut that he may not see litigants before him; and that he will neither favor the rich, nor pity the poor [...]. Four strings of pearls fall over the ears $[. .$.$] that the judges ears are to be stop'd to the entreaties of great$ ones, and to the tears of the suitors, and he must only give ear to Reason, Law, and Justice. The last four strings hang behind, to express with how much Judgement, Foresight, Premeditation, and Staidness princes ought to weigh their resolutions, and how they are to be vers'd in the affairs of the Government. ${ }^{2}$

The Chinese imperial crown was the visual representation of a set of social norms and values admired by the missionary Navarrete, those corresponding to a well-organized society driven by values of good governance exercised by

1 This headgear fell out of use during the Qing dynasty but was used in earlier periods. Hector, "Chinese Bead Curtains, Past and Present", 42.

2 Fernández de Navarrete, Tratados históricos, trat. I, cap. IX, 22. English translation available at https://babel.hathitrust.org/cgi/pt?id=uc2.ark:/1396o/t2n $58 \mathrm{tf}_{55} \&$ view=1up\&seq=9 (Lastp accessed 04.18.2021). 
the emperor as its highest authority. ${ }^{3}$ In parallel, in his description the missionary recognized the importance of the headgear as an instrument of political communication. Head ornaments served in China to affirm social status and construct a hierarchy. ${ }^{4}$ As Eugenio Menegon has pointed out, they were of great importance not only for sacred groups, but also for commoners and Chinese degree-holders. Their specific cap marked their position, since headgear was also associated with legal privileges. ${ }^{5}$ The same applied in early modern Europe. Navarrete himself was a vassal of King Philip IV of Spain (1605-1665) who in 1621 used the wording "Count-Duke Olivares, cover yourself" as he conferred Gaspar de Guzmán y Pimentel (1587-1645) the title of grandee, considered at the time to be the highest dignity of nobility. ${ }^{6}$ From that point onwards, the count-duke, as the king's favorite, was allowed to cover his head in the presence of the sovereign. This was a social honor given to only a few since it was mandatory for vassals to show their respect and subordination by uncovering their heads.

As these two examples demonstrate, sumptuary laws were equally important in both Chinese and Spanish early modern traditions. However, there was an important distinction between their external signs regarding headgear that would be the origin of future dissensions among Europeans who traveled to China: contrary to its meaning in Europe, in China it was considered impolite and disrespectful to speak to a superior without wearing a hat.

In their evangelization work in China, European missionaries faced this contradiction and were forced to set up a discussion to decide which tradition to follow when celebrating Christian rituals in China, including mass and confession. In this chapter, the topic of the Chinese hat will serve as an example when exploring missionaries' agency both in regulating their praxis in the

3 This explanation derives from The Analects of Confucius and the obligation of proper ritualistic behaviors: 非禮勿視, 非禮勿聽, 非禮勿言, 非禮勿動 fei li wushi, feliwu ting, feli li wu yan, feli li wu dong: "Do not look if it is inappropriate; do not listen if it is inappropriate, do not speak if it is inappropriate, and do not act if it is inappropriate". Translation in Lee, Warp and Weft. Chinese Language and Culture, 190-191.

4 Dorothy Ko explains about late imperial China: "Correct attire-headdress, dress, and shoes - was the quintessential expression of civility, culture, and humanity, all being ramifications of wen [...]. The inherent links among clothing, the civilizing process, and politics are highlighted in the Book of Changes: 'The Yellow Emperor, Yao, and Shun allowed the upper and lower garments to hang down, and the world was in order.' [...] Getting dressed was thus at once a cultural act, one that distinguished humans from beasts, and a political act". Ko, "The Body as attire", 12.

5 Menegon, "Deliver us from Evil", 35 fn. 70.

6 Elliot, The Count-Duke of Olivares, 45. 
missionary field and, consequently, to produce new norms regarding the use of head coverings.

The chapter is divided into three main parts. The first section briefly introduces the sources and the previous studies regarding the regulation of head coverings in the mission. The second section is devoted to the analysis of the Canton Conference of 1668 in which missionaries reached specific agreements regarding head coverings. The third section explores the different sources of authority mobilized by missionaries in their discourses in defense of their position. This analysis allows an evaluation of the importance of local conditions in these processes of creation of norms and to study missionaries in their roles as lawmakers. Accordingly, it will be possible to investigate how their European background interacted with Chinese realities. Moreover, the Chinese case of the regulation of hats will add new elements of debate to the current discussions regarding the construction of legal traditions during the process of European expansion.

Sources and Debates

Traditionally, in the field of Christianity in China, most studies on legislative activity have focused on the actions of the Papacy and the offices of the Holy See in direct relation to the well-known Chinese Rites Controversy. ${ }^{7}$ The magnitude of the dispute involved eight popes and the Emperor 康熙 Kangxi $(1654-1722) .{ }^{8}$ Therefore, their consecutive interventions, through decrees, bulls, and legations, have drawn the attention of historians since studies of the missions began until today. ${ }^{9}$ When descending from the central institutions to

7 Following Claudia von Collani's definition, the Rites Controversy was a series of debates among different parties "about the participation of Christians in certain non-Christian religious or secular rites and ceremonies in Asia (China, Japan, India, Indochina). Connected with the rites controversy was the accommodation of missionaries to local cultures and the question of an indigenous terminology and to what extent new Christians had to use Western sacramentals and observe the European canon law". Relevant problems were the translation of the term God and Chinese ritual practices of honoring family ancestors and Confucius. The latter were considered civic and not religious cults by some, while others took the opposite view considering these actions incompatible with Christian orthodoxy and therefore superstitious. Collani, "The Jesuit Rites Controversy", 891. See also Pavone, "Riti Cinesi", 1324-1329.

8 For the history of the Rites Controversy, see Minamiki, The Chinese Rites; Mungello, Curious Land; Cummins, A Question of Rites; Collani, "The Jesuits Rites", 891-917.

9 Among many other authors, see, for example: Di Fiore, La legazione Mezzabarba, 1989; Rule and Collani and Hughes, The Acta Pekinensia, 2015, reprint 2019; Gong Yingya, "The Edict of toleration", 178-182. 
the mission field, one finds that, in the last years, scholars have also devoted their efforts to the study of the role of the Jesuit visitors, as illustrated by the cases of Alessandro Valignano, SJ (1539-1606) and André Palmeiro, SJ (15691635). Their duty to inspect and judge missionary policies in Asia also involved drawing up rules for missionary life that have been evaluated by scholars, too. ${ }^{10}$ When discussing normativity in Asia, another aspect has also played an important role in the historiography of the last decade: casuistry. Theologians identified, discussed, and settled moral principles based on the evaluation of particular 'cases of conscience.'11 In the missions, missionaries found numerous doubtful cases when evangelizing. Specialists such us Giovanni Pizzorusso, Charlotte de Castelnau-L'Estoile, and Giuseppe Marcocci, among others, have therefore analyzed the missionaries' correspondence that gives testimony to the continuous consultations posed by them as well as the resolutions provided by the authorities including the congregations from the Propaganda Fide in Rome and the higher ecclesiastical authorities within the orders. ${ }^{12}$

Considering that in the studies of casuistry and the papal and visitors' actions, norms were produced by central authorities, it is easy to assume that norms in the mission field were also thought up and systematically imposed by central institutions. ${ }^{13}$ This may have been influenced by the archival selection: in studies of the mission, there has been a tendency to focus on the European archives of the highest entities instead of the local archives of the orders. ${ }^{14}$ But it was also because resolutions, opinions, and enquiries are usually found in the archives as part of theological compilations labeled as "miscellaneous" which means reviewing sources requires a great effort. Apart from the fact that historiography has focused its attention on these cases, there are two other reasons that could explain this widespread connotation of norms as a product of central authorities. First, we naturally assume that in the ancien régime those in the lower stratum turned to superiors for decision making and there

10 Brockey, The Visitor, 2014; Schute, Valignano's Mission. See also Metzler, "Mezzi e modi", $38-5$ o.

11 For a general examination of the method of casuistry in the early modern period, see Prodi (ed.), Disciplina dell'anima; Prodi, Una storia della justicia.

The analysis of the dubia circa sacramenta is a well-known example of this. See, among others, Pizzorusso, Charlotte de Castelanu-L'Estoile, and Broggio (eds.), "Administrer les sacrements"; or Marcocci, A consciencia de um império, 2013.

For a perspective on casuistry in the missionary field, see also Ehalt (Chapter 8) in this volume.

Archives such as the Propaganda Fide historical archives, Ajuda Library, and the Vatican Library have been historically visited more. The Jesuits and the Archives of the House of the Superior General (ARSI) were an exception because of their fourth vow of special obedience to the pope. 
is general agreement on the fact that matters of relevance should be resolved by those higher in the hierarchy. ${ }^{15}$ Second, Chinese missions were not part of lands conquered by Europeans. Consequently, the subsidiary nature of the missions, with respect to the Portuguese and Spanish empires, is added to the previously mentioned predominant European-centered-state perspective on legal history. ${ }^{16}$ Although these assertions have been recently put into question by specialists, there is still a need to study local practices to write about legal history from a global perspective. ${ }^{17}$

With this in mind, this chapter uses the example of head coverings in China, in which the initial resolution of a norm takes place in the missionary field by the missionaries themselves. For this purpose, this chapter mainly focuses on two manuscripts that have so far received little scholarly attention, which are preserved in the archives of the Santo Tomás Convent (Avila, Spain), where the majority of documents regarding the Province of the Holy Rosary of the Dominican Order - concerning the Philippines, Japan, China, Formosa, and Tonkin-are stored. ${ }^{18}$ The first manuscript is entitled Respuestas a unas objeciones de las cortesías de los bonetes de China \& a firmado por varios PP. en la reclusión de Canton (incluido el VP. Fr. Antonio de Sta. María) (hereinafter Respuestas) and the second is called Dudase si en China es conveniente que asistan los cristianos a la misa cubierta la cabeza (hereinafter Dudas). ${ }^{19}$ These manuscripts are especially valuable because they were part of what has come to be known as the Canton Conference, a series of discussions held by the

15 As pointed out by Ehalt (Chapter 8), in this volume, citing Josef Wiki (1961): "estos casos [de consciência] envolviam temas como comércio, direitos de herança, matrimônios e otros, exigindo 'imediata e segura solução, [...] mas que pelas graves consequências não podiam nem deviam ser resolvidas por un simples missionário". Ehalt, "Casuística nos Trópicos", 500.

16 For a reflection on the idea of law in the Iberian empires see Bastias Saavedra (Chapter 1) in this volume.

17 See also, Cardim, Herzog, Ruiz Ibáñez et al., Polycentric Monarchies; Duve, "What is global legal history?", 1-43; Bastias Saavedra, "Diversity as Paradox", 1-17; Duve, "Pragmatic Normative Literature".

18 I have considered both documents separately given their contents and titles. Nevertheless, the box in which they are preserved contains an index in which both documents come under the same reference: "Respuesta del P. Navarrete a ciertas objeciones sobre el uso de los bonetes". Sección Ritos Chinos o35. Tomo 3. Tratados misceláneos (1637, 1669, 1717). Carpeta 6 , fols. $324 \mathrm{v}-342 \mathrm{v}$. The handwriting would indicate that these are copies of original documents, probably from the 18 th century.

19 "Dudase si en China..." is a second manuscript version that is also printed in the Controversias written by Navarrete, published in 1679 . Navarrete, Controversias, Trat. 4, fols. 222r-227r. Anna Busquets included a description of this manuscript in her PhD dissertation about him. Busquets, Los Tratados Históricos, 279. 
missionaries between 1667 and 1668 in Guangzhou, China. In the history of the Chinese mission, it is a rare example of a regulated discussion to look for agreements. Moreover, the importance of these meetings also comes from the fact that this was the first time the three main religious orders working in China_Jesuits, Franciscans, and Dominicans—are found together discussing the issues that most concern them. ${ }^{20}$

The analysis of the hat controversy not only allows a bottom-up approach, but also consists of an element often overlooked in the scholarship. Specialists have historically tended to focus on the regulation of more controversial aspects, such as the practices of ancestor worship and sacrifice to Confucius, which were central issues debated as part of the Rites Controversy. ${ }^{21}$ Recent studies on the sacrament of marriage in the missions have opened new lines of research into the regulation of Christian rituals. ${ }^{22}$ Yet, the question of the hat was not a direct and obvious attack on Christian orthodoxy, as were cases of marriage and concubinage. Therefore, the hat regulation provides us with a less controversial aspect in which it is easier to find elements that highlight processes of consensus within the missionaries' policies that had been neglected because of a preponderant understanding of the mission as involving quarrels between missionaries merely because of their different orders or nations.

Further, the issue of the hat did not produce much documentation because missionaries quickly chose to adapt their European custom to Chinese etiquette. Soon after their arrival in China, missionaries became aware of its intricate sumptuary laws. For this reason, in 1613, Father Nicolò Longobardo, SJ (1559-1654), superior of the Chinese mission, sent Father Nicolas Trigault, SJ (1557-1628) to Rome to negotiate several questions regarding the Chinese liturgy, including the issue of head coverings. ${ }^{23}$ With the support of Cardinal Roberto Bellarmino, SJ (1542-1621), the most prestigious theologist in Rome at the time, Trigault requested permission from the Holy See to wear head coverings during mass. ${ }^{24}$ In response, Pope Paolov $\left(155^{2-1621)}\right.$, in the brief Romanae

\footnotetext{
20 Metzler, Die Synoden, 11-21.

21 Standaert, The interweaving.

22 Collani, "Mission and Matrimony", 11-31; Catto, "La monogamia nella poligamia", 7-22. See also Meynard, "Could Chinese Vegetarians be Baptized? Part 1", 75-145; Meynard, Could Chinese Vegetarians be Baptized? Part 2", 285-341.

23 Jesuits also requested permission to translate the Holy Scriptures into classical Chinese, as well as authorization for future Chinese priests to celebrate mass, recite the breviary, and administer the sacraments in classical Chinese. For more on the Trigault trip to Rome, see Lamalle, "La propagande du P. Nicolas Trigault en faveur des missions de Chine (1616)", 46-120; Seah, "The 1670 Chinese Missal", 86-120.

24 Entitled De Missa celebranda tecto capite. Seah, "The 1670 Chinese Missal", 93-94. Transcriptions of the petition and decrees by the Holy Office can be found in Bontinck, $L a$ Lutte Autour, 405-411.
} 

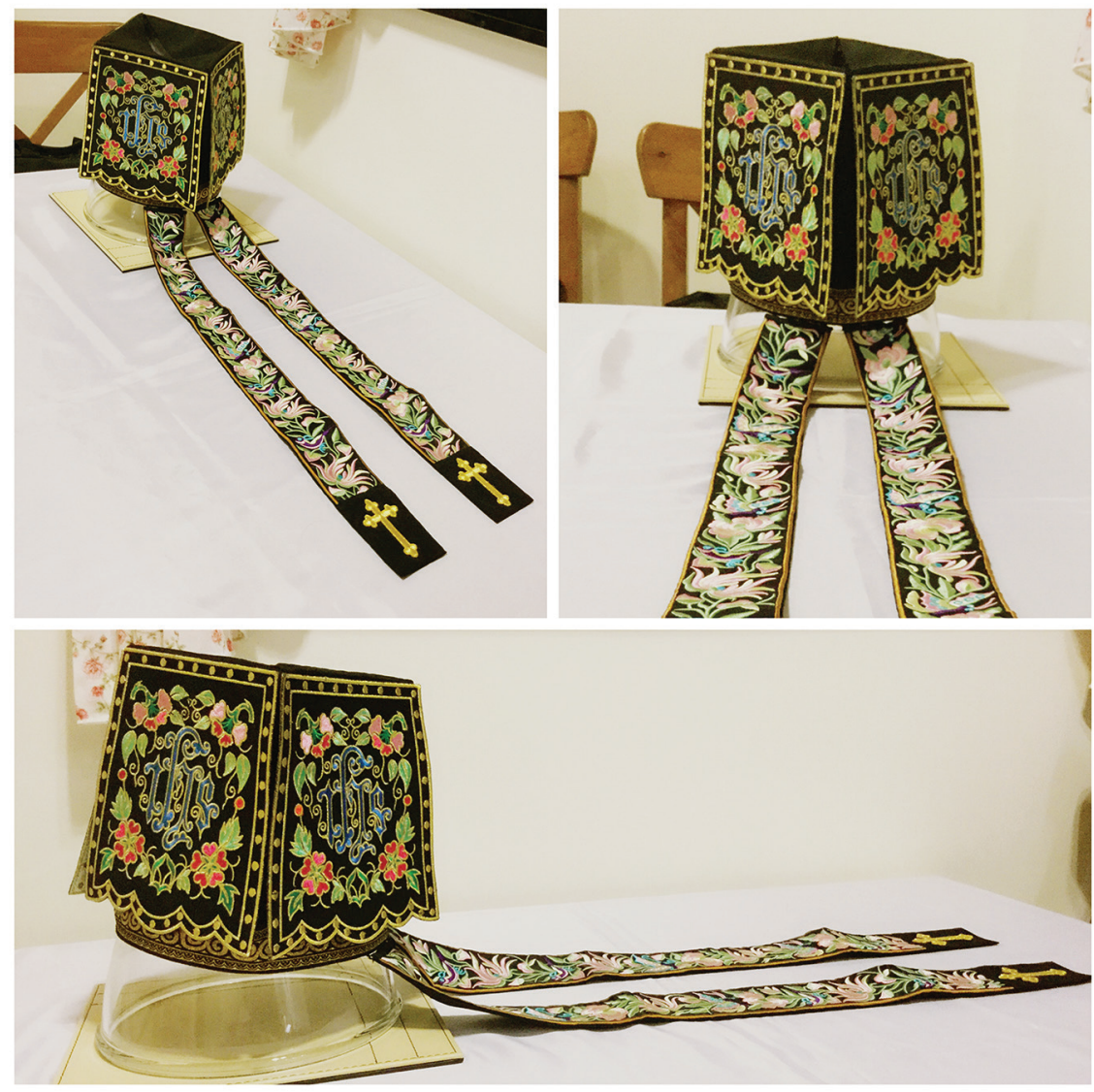

FIGURE 9.1 Reproduction of a 祭巾 Jijin. Domus Serapahica project.

COURTESY OF MR. HO LONG FRANCESCO LI

Sedis Antistes, granted that the Chinese could wear hats, unlike in Europe, and missionaries were permitted to wear head coverings during the Divine Office, the so-called 祭巾 Jijin (Figure 9.1). ${ }^{25}$

25 Its transcription can be found in Bontinck, La Lutte Autour, 411-412. Giulio Aleni (15821649) gives a well-known description of this special hat in his 彌撒祭義 Misa jiyi: "It has a square top, a round bottom, and four faces. To the top of each face an embroidered square panel is fixed, with three strings hanging from each top corner. One corner faces the front, and from the back hang two long ribbons". Translation by Gregory Dipippo in http://www.newliturgicalmovement.org/2018/o8/the-chinese-sacrificial-hat-and.html (last accessed 05.25.2020). 巾 Jin (soft hat) was an everyday type of headwear that marked the person's affiliation to the church. The character 祭 refers to the action of offering a sacrifice. Zorkina, "Taoist garments in Rituals and Monastic Life", 163. See also Motoh, “Orphan(ed) Scroll", 139-159. 
Paolo V's allowance of head coverings during Christian rituals continued for over 300 years. On July 31, 1673, Pope Clement x (1590-1676) once more confirmed permission to celebrate mass coperto capite (with the head covered). And, only in 1924, the use of the Jijin head covering was eventually abolished in the First Chinese Council held in Shanghai. ${ }^{26}$ As a result, the impression given is that the question of head coverings was a more static and less disputed phenomenon compared to other questions of the Church in China. Nevertheless, the preservation of the Respuestas and Dudas manuscripts reveals that, behind this apparent agreement, there was in fact an ongoing passionate debate between missionaries on the wearing and not wearing of a hat, even if this had little resonance in the Roman central quarters compared to other more controversial matters.

There are also other reasons that the use of a Chinese sacrificial hat and permission to appear covered during mass and all sacred rituals have not yet received detailed attention. For example, as a liturgical element, the use of the hat has been more typically associated with the history of clothing, fashion, and material culture. ${ }^{27}$ And, even from that point of view, it has been difficult for scholars to reconstruct these realities, particularly due to the lack of consistent implementation of the Catholic missionary enterprise in Asia, the periodical persecutions faced by missionaries, and the natural degradation of cultural materials over time. Recent contributions have begun to redress such gaps in the literature. ${ }^{28}$

Bontinck, La Lutte Autour, 387-388. See also Concilium Sinense, ed. Primum Concilium Sinense anno 1924 a die 14 maii ad diem 12 iunii in ecclesia S. Ignatii de Zi-Ka-Wei celebratum: acta, decretal et normaa, vota, etc.

The habit was one of the central elements of the missionaries' identity. Accusations of not respecting the vow of poverty by using silk garments and luxurious ceremonial dresses and hats were common in Asian missions. See Zampol, "Purple Silk and Black Cotton", 136-155; Menegon, "The habit that hides the monk", 30-49.

Sanfilippo, "Labito fa il missionario", 610-620; Hsia, "From Buddhist Garb", 143-154; Brockey, "Authority poverty, and vanity", 179-222; Menegon, "The habit that hides the monk", 45-46; Amsler, Jesuits and Matriarchs, 13-31; Zampol, "Purple Silk and Black Cotton", 137-155.

To which the classical works of Bontinck, CICM, La lutte autor de la liturgie chinoise; López Gay, La liturgia en la misión del Japón; and Margiotti, OFM, Il cattolicesimo nello Shansi, should be added. Previous studies have focused on clothing and bodily practices, especially regarding dress code, as representations and external signs of the adaptability or non-adaptability of Catholic missionaries to non-European contexts. This adaptability, according to Menegon, has been studied from different perspectives including the classical accommodation approach, the paradigm of the Baroque "dissimulation", and the more general framework of the dialogue of cultures. Menegon, "The habit that hides the monk", 45-46. 
The manuscripts under discussion here present a different perspective: the discussion about the regulation of the use of head coverings during Christian rituals. This chapter, first, studies the legal mechanisms used by missionaries to regulate their practice beyond their superiors. Second, it analyzes how different sources of authority were drawn upon to justify the use of Church or Chinese custom in the celebration of mass and confessions in the Chinese context. Read in conjunction, the two selected manuscripts of 1668 offer a picture of the different positions and argumentations adopted by missionaries when discussing the regulation of the use of hats in the Chinese mission. After these documents were written, missionaries continued to submit further statements on the issue. However, this chapter focuses only on the initial argumentations at the beginning of the controversy. This decision responds to the objective of understanding the discourses surrounding and the process of creation of the norm about head coverings. The intention is not to reconstruct how the question of the hat was dealt with by Catholics and the subsequent decisions made by all the participants over time, nor is the focus on the results of the missionaries' debates with the objective of understanding their degree of adaptation to Chinese culture. On the contrary, by moving away from that classical dichotomy, this chapter reflects on the complexity of the transcultural experiences undergone by missionaries in China and how these affected their normative practices, thus illustrating the normative pluralism that characterized the early modern period.

\section{Head Coverings in the Canton Conference of $1667 / 1668$}

This section discusses how the question of head coverings was discussed in the Canton Conference of 1667/1668. The first part (3.1) shows how broader guidelines for the discussion and definition of norms were laid out by the missionaries, revealing some preestablished mechanisms for the revision and collective authorization of norms at the local level. The second part of this section (3.2) explores how the norms regarding head coverings were decided and certified, revealing that decisions by higher or more prestigious authorities did not necessarily end the discussion but could in fact lead to further debate. The Dudas and the Respuestas are a reflection of these ongoing conflicts of norms.

\subsection{Rules for Finding Rules for the Chinese Mission: The Canton Conference of $1667 / 1668$}

The manuscripts under discussion here were produced in the last months of 1668. 53 years had passed since the Pauline brief had allowed the use of head 
coverings in the Chinese missions, after which many things changed. Trigault had returned to China in the 1610s, while the Chinese mission had been elevated to the status of Vice-Province in 1618 although it remained under the jurisdiction of the Japan Province. At that time, Jesuits kept monopoly of the missions in China and operated legally within the Portuguese Padroado by which the Church delegated the administration of the local churches to Portuguese monarchs. In the first years of the mission, they chose to adopt the Buddhist identity but later made the decision to change to the Confucian literati fashion and grew their hair long. ${ }^{29}$ In 1621 , they issued a compendium of rules for the new Vice-Province in which they also included instructions about hair. That same year "some of Nicolas Trigault's recruits slipped into China from Macau 'in literati costumes, with long beards, hair grown out and tied on their heads in Chinese fashion.'”30

In 1633, Pope Urban VIII (1568-1644) issued the bull Ex debito pastoralis and opened China and Japan to missionaries of other orders and societies. The first Dominicans arrived in 1631, followed by the Franciscans in 1633. These were major changes not only because the mission was restructured, but also because the presence of different orders made the controversy over Chinese Rites public when the Dominican Juan Bautista Morales, OP (1597-1664) brought the question to Rome. ${ }^{31}$ Furthermore, in 1622, Rome had created the Sacred Congregation for the Propagation of the Faith, known as the Propaganda Fide. ${ }^{32}$ This institution sought to strengthen Rome's position within the Spanish Patronato and the Portuguese Padroado in order to restore the spiritual char-

29 This change has usually been attributed to Matteo Ricci at the suggestion of the Chinese literatus, 翟太素 Qu Taisu (1549-1611). See, for instance, Menegon, “The habit that hides the monk", 33. Mathew Brockey, on the contrary, proves that this transformation was begun eight years earlier by Alessandro Valignano (1539-1606). Brockey, "Authority, poverty, and vanity", 202, 204.

Brockey, Journey to the East, 78. The Jesuit Visitor, André Palmeiro, SJ (1569-1635) also wrote a separate report on clothing to control excesses in 1628. Brockey, The Visitor, 252253. See also Menegon, "The habit that hides the monk", 33, 45-46.

$31 \quad$ He submitted to Propaganda 17 propositions and as a result Pope Innocent x (1574-1655) condemned the Chinese Rites on September 12, 1645. Jesuits reacted by sending Martino Martini, SJ (1614-1661) to present the case in Propaganda. The Holy Office judged that the ceremonies could be allowed to the Chinese Christians given their civil and political character. Finally, Pope Alexander vi confirmed it by a decree on March 23, 1656. Minamiki, The Chinese Rites controversy, $25^{-32}$.

Established by Pope Gregory Xv (1554-1623), it was responsible, in the name of the Pope, for promoting the spread of the Catholic faith and directing the life of the Church in the mission lands. Also, in parts of the world which had not yet been Christianized, there was a lack of regular ecclesiastical hierarchy or it was at an early stage of development. Dowd, Rome in Australia, 43. 
acter of missionary work. Consequently, after 1620, the Chinese mission was formed of members of diverse religious orders, of different nationalities, and working under various privileges and institutional dependencies. ${ }^{33}$

The situation was complicated further when considering that the missionaries were primarily dependent on the local imperial power to carry out their work of evangelization. The 165 os and 166os were turbulent times in China. The transition from the Ming to the Qing dynasty involved a long period of internal conflict including war and destruction, epidemics, and famines. ${ }^{34}$ In addition, missionaries needed approval from the rulers of the new dynasty. To gain the favor of the new Emperor 順治 Shunzhi (1638-1661) they offered their technology and services, acting as scientists and diplomats, and adopted without reservation the new Qing robes and their official hats with rank buttons. ${ }^{35}$

Under the following emperor, Emperor Kangxi, Christianity experienced considerable growth, benefited particularly by the crucial positions achieved by the Jesuits in the imperial Astronomical Bureau (欽天監 Qintianjian), with Adam Schall von Bell, SJ (1592-1666) in the forefront. ${ }^{36}$ In 1661, the Emperor died unexpectedly, and a new period of persecutions began. During the Oboi regency (1661-1669), 楊光先 Yang Guangxian (1597-1669), a Confucian scholar allied to the Muslim Astronomers, delivered a series of accusations against Schall, among others, blaming the Jesuits for the dissemination of pernicious doctrines and accusing them of falsifying the calendar and conspiracy against the state. In 1665, this conflict resulted in the proscription of Christianity, the imprisonment of Schall, and the confiscation of the missionaries' properties. ${ }^{37}$ In addition, all missionaries were expelled to Guangzhou with the exception of

See Mensaert, "L'etablissement de la hiérarchie", 369-466; Pizzorusso, "Per servitio della Sacra Congregatione", 201-227.

34 For the causes of the fall of the Ming dynasty and the Manchu conquest of China, see Wakeman, The Great Enterprise; Struve, The Qing Formation. See also Chan, "Late Ming Society and the Jesuit Missionaries", 153-172.

35 Menegon, "The habit that hides the monk", 41-42. As the Dominican friar Alcober wrote in a letter in 1733 to his cousin: "La figura mía exterior es muy extraña, porque aquí no llevamos hábito. Vamos vestidos a la tártara, barba larga, rapada la cabeza como un galeote. Lo demás del vestido no cuento, porque no lo has de poder entender". González, Historia de las misiones, 204-205 fn. 22.

36 On the missionaries' role in producing calendars in the late Ming and early Qing dynasties, see Li (Chapter 10) in this volume.

37 In addition to Schall von Bell (16o6-1682), Verbiest, SJ (1623-1688), and Magalhães, SJ (1610-1677) remained. On May 18, 1665, five Christian officials in the Astronomical Bureau were sentenced to death. Alden, The Making of an Enterprise, 145-146. See also Jami, Revisiting the Calendar Case, 459-477. 
those who remained at court and a group of Dominicans that continued their apostolate underground in the regions of Fujian and Jiangnan. ${ }^{38}$

For several reasons, the period of the missionaries' house arrest in Guangzhou, from March 25, 1666 until September of 1671, was particularly relevant for the Catholic enterprise. First, it was a time in which Chinese Christians assumed greater leadership in the administration of the Church's activities due to the absence of the missionaries. ${ }^{39}$ Second, members of the three orders lived together in the Jesuit residence of Guangzhou and used their time to work on writing Christian liturgical books in Chinese and translating the main Confucian texts into Latin. ${ }^{40}$ Third, as this chapter highlights, missionaries undertook the difficult task of seeking agreement on the question of the Chinese Rites and created a set of norms that, in some cases, remained.

It was during this five-year house arrest in the Pearl River Delta when the Respuestas and the Dudas were written, as part of the Canton Conference which lasted for 40 days (between December 18, 1667 and January 26, 1668) and involved the participation of 25 missionaries (21 Jesuits, three Dominicans, and one Franciscan). ${ }^{41}$ The difficulties in the implementation of the Church policy on the ground often gave rise to multiple doctrinal interpretations and was therefore a source of continued debate. The Chinese mission was not different in that sense. For this reason, the objective of the Canton Conference was to preserve the uniformity of preaching and action in the missions. One of the Jesuits, the Italian Prospero Intorcetta, SJ (1626-1696), explained the objective of the conference in a letter to the Propaganda Fide in 1672:

In view of our uncertain future, the Canton exiles would certainly have the time to examine, to great benefit, the books, rites, customs, and practices of our Mission [...]. Mainly because of the desire of the fathers of St. Dominic, supported by all of us, the Father Vice-Provincial resolved to celebrate a kind of synod in which we would discuss all the controversies

38 For this episode, see Appendix I, "Canton: Internment and flight", in Cummins, The Travels, 412-424.

39 See, among others, Raini, "Catechisti e capi", 97-156; Entenmann, "A Mission Without Missionaries", 31-54; Entenmann, "Catholic Clergy", 389-410.

40 The Confucius Sinarum Philosophus sive scientia Sinensis latine exposita (Paris, 1687) was the first complete translation of the Four Books into a European language. For an analysis of the book production, see Golver, "The Canton-Macau as a lieu de savoir", 214-233.

During the confinement two missionaries died, Inácio da Costa, SJ on May 11, 1666 and Michel Trigault, SJ in September of 1667 . For an analysis of the nationalities, ages, education, and experience on the mission of those missionaries arrested in Guangzhou, including graphics, see Esquivel, El confinamiento de los misioneros, 230-244. 
between us and with the members of other religious orders, and the need of uniformity for the preaching of the Holy Gospel. ${ }^{42}$

Father Intorcetta described the conferences as "a kind of synod" which is symptomatic of the difficulties they encountered when trying to implement in these territories the more orthodox instruments used by the Church to regulate their praxis. ${ }^{43}$ Spaces of negotiation were part of the Catholic tradition and the synod was one of them. From the point of view of canon law, a synod was "a gathering of church representatives to study daily problems of the spiritual life, give an impetus or restore ecclesiastical laws, promote divine worship and religious practice." 44 The Canton Conference directly responded to these special needs. ${ }^{45}$ They founded a system to clarify the practice of the Church in China and reach their objective of providing a set of common rules for pastoral activity in the mission.

The missionaries established their own procedure for conducting the conference and defining the new rules for the mission: discussions would be resolved by vote under the presidency of Vice-Provincial Feliciano Pacheco, SJ (1622-1687) with the Italian Jesuit Giovanni Francesco Ferrari, SJ (16o9-1671) acting as Secretary. ${ }^{46}$ Navarrete would speak for the Dominicans and Antonio de Santa María Caballero, OFM for the Franciscans. Given the disparity in the number of missionaries of each order, Navarrete also claimed the right to speak for the three Jesuits living in Beijing and the five Dominicans that were hidden in the inland provinces. The Dominican wrote down this decision and highlighted his claims in his Controversias in this way:

Based on what has been said, the Fathers of the Society [of Jesus] agreed to propose some points so that, once everyone has made their opinion felt, it could be decided by vote how to proceed. I became worried because we were only three, one belonging to the Franciscan order, and

42 Italics are mine. "Frà queste icertezze al nostro flato futturo, gli esiliati in Canton havemmo certo il tempo per esaminare, non senza gran fruto, i libri, i riti, gli usi, e conseutudine della nostra Missione [...] desiderandolo li Padri principalmente di S. Domenico, col parere di tutti li nostri si risolvè il Padre Vice Provinciale di fare un come Sinodo, nel quale trattassimo tutti insieme le cose controverse tra noi, e gli altri religiosi, e d'una uniformità necessaria per la predicatione del Santo Evangelio". Cicé, Acta Cantoniensia, part. I, 16-17. Missionaries in their writings also refer to these conferences as juntas, discusiones, or disputates.

44 Vaquero, Diccionario, vol. 4, 2487.

45 See also Metzler, Die Synoden, 11-43.

46 Fernández de Navarrete, Controversias, Trat. IV, 190. 
19 of their Fathers [Jesuits]. It was clear that their votes would always prevail, with which they could do what they wanted. ${ }^{47}$

This excerpt describes how they established the voting system, but it is also noteworthy that they were following the disputatio logic of late scholasticism in their procedure. This method consisted of announcing the question that would be discussed by the participants beforehand. Nevertheless, it was an open and pluralistic process. During the celebration of the conference, Chinese catechists who lived in the house were consulted when certain doubts on local uses arose during their discussions. Navarrete, in his Controversias, gives an example of their intervention when there was a disagreement between the participants about the presence of the soul in the funerary tablets:

Refers particularly to the tablets of the deceased and Confucius. The author explains the two Chinese terms I Xin at will; and to speak with total security in this matter, I called Brother Antonio Fernandez [...], he told me it meant that the souls came to rest on the tablets [...]. The next day I asked the same question to Juan, the catechist, and he answered the same. During the afternoon I asked bachiller Marcos, he answered in the same way and he wrote it with his own hand. ${ }^{48}$

In total, three different Chinese brothers were consulted to clarify the question. In addition, further information was available to all members through some collections that had been brought to Guangzhou from the Macau college archives, including manuscript texts and print books both in Chinese and Western languages. ${ }^{49}$ Furthermore, the missionaries also maintained continuous contact with the outside world and their exchange of letters was not interrupted. ${ }^{50}$ The final resolutions of the Canton Conference were condensed into 42 articles in the form of an act. Several copies are preserved in archives around Europe, although most of these copies do not include the minutes of

$47 \quad$ Fernández de Navarrete, Controversias, Trat. IV, 190.

48 Fernández de Navarrete, Controversias, Trat. VII, 396.

49 Noël Golvers provides a list of the Western printed books in Golvers, "The Canton-Macau as a lieu de savoir", 228-232. See also 223, $225 \mathrm{fn}$. 35 .

50 At the beginning of their detention, Chinese authorities conducted a rollcall and missionaries were tightly guarded. These measures were relaxed over time and from the summer of 1668 onwards they increasingly enjoyed freedom of movement. Cummins, A Question of Rites, 144-145. Golvers refers to a brief period of break in 1667 due to some discordances with magistrates. Golvers, "The Canton-Macau as a lieu de savoir", 226, 225 fn. 38. 
the conference. ${ }^{51}$ Its resolutions had the objective of providing a uniform regulation for the liturgical praxis and should have put an end to previous disagreements and rivalries within the mission. Most of them were devoted to the proper administration of the sacraments, but there were also articles focused on the regulation of the liturgical calendar, nocturnal gatherings, religious imagery, and the catechesis for children, among others. ${ }^{52}$

\subsection{The Customs of the Church or the Style of the Land: The Question of Head Coverings in the Canton Conference}

The topic of attending mass with or without head coverings played an important role in the Canton Conference. Eleven out of the 42 articles related to mass and three of them referred to clothing and bodily practices. The privilege conceded by Paolo V in 1615 to have one's head covered during mass was brought back to the table in 1667 , though it is not clear who instigated this. The Franciscan Santa María in a letter dated November 14, 1668, indicated that it was both António Gouvea, SJ (1592-1677) and Father Feliciano Pacheco who made the request to celebrate mass without a hat, at least within the confines of the Guangzhou house and its chapel. ${ }^{53}$ But the Italian Dominican Domenico Sarpetri, OP (1623-1683) accused Santa María of provoking this controversy himself. However, Jesuit Father Jean Valat, SJ (c. 1614-1696) defended him, stating that it was the Jesuit fathers who had made the proposal. ${ }^{54}$

Regardless of who began the discussion, the issue was debated in the conference. The quaestiones disputatae asked "If it is convenient for the priest to celebrate mass with his head uncovered, and for the Christians to attend in this manner and receive communion?"55 Concerning this passionately contested issue, they finally reached the following rule:

$5^{1} \quad$ They were printed in 1700 and known as the Acta Cantoniensia Autentica, part 2, fols. 19-42 by Luis-Armand Champion de Cicé, MEP (1648-1727). A German translation of the 42 resolutions can also be found in Metzler, Die Synoden, 24-28. To see on which documents the author based his translation see p. $28 \mathrm{n}$. 11. Navarrete included all the articles with his comments as part of his Controversias. Fernández de Navarrete, Controversias, Trat IV, 19o. For this work, an autographed version preserved in the Roman Archives of the Jesuits (ARSI) with the reference Fondo Gesuitico $722 / 12$ was also consulted.

$5^{2} \quad$ For a general analysis of the content of all articles, see Esquivel, El confinamiento de los misioneros, $265^{-273 . ~}$

53 Sinica Fanciscana, Vol. IX, 1026.

54 Copies of the testimonies of Jean Valat and Adrian Grelon supporting Santa María can be found in APSR, Ritos Chinos 35, Tom. 3, leg. 6, fol. 324r-324v.

Fernández de Navarrete, Controversias, Trat. IV, fol. 222r. 
In the presence of the Chinese no reverence can be made by removing the hat from the head, but instead embrace all kinds of signs of respect for a man of such high stature, the Chinese should be always covered: Christian mysteries require the greatest reverence, which must be demonstrated in the presence of the locals; neophytes who attend the Holy Sacrifice, who help the priest serving at mass, or who receive Holy Communion, should have their heads covered with a cap to honor the great mystery. ${ }^{56}$

As this text shows, first, they permitted that Christians attending mass should have their heads covered and, second, that the priest's assistants should also be covered. This was voted by a majority. However, the three French Jesuits Adrien Grelon, SJ (1618-1696), Jean Valat, and Humbert Augery, SJ (1610-1672), the Portuguese Jesuit Manuel Jorge, SJ (1621-1677), the Spanish Dominican Felipe Leonardo, OP (1627-1677), and the Spanish Franciscan Santa María voted against the ruling. ${ }^{57}$

Before sending the final resolutions to the superior general, some members of the conference decided to seek the approval of Luís da Gama, SJ (1610-1672), the Portuguese Jesuit Visitor of Japan and China residing in Macau. Father da Gama, after studying the matter over the summer, suggested that these two points agreed in the conferences should be changed because he considered that attending mass with head coverings went against the customs of the Church. ${ }^{58}$ Instead, the visitor proposed modifying both articles so that

$56 \quad$ "Cum apud Sinas pileum e capite deponere nulla sit reverentia; quin immo omnis externa Veneratio tam homini, quam vero, aut putato Numini tecto capite semper à Sinis exhibeatur: Christiana autem mysteria summam exigant reverentiam, quae praesentibus etiam Ethnicis probetur: Neophyti sive sancto Sacrificio assistantes, sive sacerdoti sacris operanti in servientes, sive etiam ad Sacram Communionem accedentes ob tanti mysterii reverentiam caput pileo tectum gerant". BNCR, Fondo Gesuitico, ms. 1257.18, fol 163r; ARSI, Fondo Gesuitico, 722.12, fol. 3 r.

57 Bontinck, La Lutte Autour, 123. Santa María argues that French Jesuit Jaques Le Faure, SJ (1613-1675) and Pietro Canevari, SJ (1596-1675) were in favor of head coverings during mass and he added: "el P. Juan Valat, llamáronle entonçes a confessor a un padre moribundo, el P. Manuel Jorge por no se opponer al voto del padre viceprovincial latenter se levantó y se fue a su retrete. Los demás padres que a mí me avian llamado para el intento del celebrar sin virete [Gouvea and Pacheco], se viraron [their votes] allí por acomodarse al parecer del padre vice provincial y padre ançiano Canavari lisiados in capite, y dexáronme a mí solo, y por esso quando dixe mi parecer, que sin virete, no faltó quien submissa vocce, que oy, çumbó de mí". Sinica Franciscana, vol. IX, 1026.

58 Bontinck, La Lutte Autour, 123-124; Cummins, A Question of Rites, 156-157; Cummins, The Travels and Controversies, 416. 
Christians could be covered during mass, with two exceptions: acolytes in surplices should be bareheaded (art. 20) and Christians' heads should also be uncovered when receiving communion (art. 22). His new proposal is found in Table 9.1:

TABLE 9.1 Articles 20, 21, and 22 of the Canton Conference suggested by the Visitor da Gama

Latin

Art. 20

Qui Sacerdoti ad altare

operanti inservit, $(g)$ si sie

superpelliceo indutus, inserviat

capite discooperto; secùs si sine

superpelliceo

Art. 21

In Missae ministerio non abrogetur usus superpellicei

Art. 22

Accedentes ad Sacram

Comunionem Neophyti caput

discooperiant: in Missa autem

pileati assistant: Si quis autem

propter inopiam pileo careret, non

id illi exprobratur

\section{English}

If the Mass servant (g) wears

surplice, he should uncover his head;

otherwise, he should be covered

The use of surplice during Mass is not abrogated

Neophytes should approach the Holy Table with their heads uncovered. If they attend Mass, they can cover their heads. If someone because of his poverty does not have headwear he should not worry.

SOURCE: CICÉ, ACTA CANTHONIENSIA, FOLS. 26R-27R; FERNÁNDEZ DE NAVARRETE, CONTROVERSIAS, TRAT. IV, FOLS $219 \mathrm{R}$

Some of the conference members were surprised by this response. The suggestion of using the European tradition for the mass servants and during holy communion meant, for them, that the visitor was rejecting the significance attributed by the Chinese to head coverings. Most missionaries that were taking part in the conference tried to change his mind, and his decision gave rise to numerous memorials and letters, especially towards the end of 1668 . In fact, the disagreements he provoked with his intervention led to the existence of the sources that give testimony to what was said about head coverings during the conferences. 59

59 "Como en las resoluciones escritas hubo diversidad grande de pareceres, y demasiada oposición, es conveniente manifestar aquí lo principal de la dificultad, con lo que acerca de ella se dixo de una, y otra parte”. Fernández de Navarrete, Controversias, Trat. 4, fol. 22 or. 
Thus, both the Respuestas and the Dudas appeared during this period. These manuscripts illustrate the arguments of the early stages of this controversy. The manuscript of the Respuestas, dated September 17, 1668, is signed by those who voted in the conference against the permission to be covered, with the addition of the Italian Jesuit Andrea-Giovanni Lubelli, SJ (1611-1685) while the Dudas manuscript was concluded by Navarrete on September 25, 1668. ${ }^{60}$ Afterwards, on October 10, 1668, Father Giovanni Francesco Ferrari submitted a further statement in defense of the primitive articles that allowed the attending of mass while wearing a hat. ${ }^{61}$ In response, da Gama ordered Adrien Grelon to write a short treatise exposing the conflicting view. ${ }^{62}$ Father Santa María also submitted a treatise to the General of the Jesuits with his opinions on the question and several letters arrived at the Jesuits' Roman Curia complaining about the visitor's intervention in the matter. ${ }^{63}$ Finally, on December 10, 1668, da Gama sent the act, together with a document, signed by 15 missionaries from the Chinese mission, that included the articles 20 and 22 from Table 9.1 in its original version but merged into one (Figure 9.2). ${ }^{64}$

The intervention of the Portuguese Jesuit Visitor da Gama was interpreted in different ways by the conference participants. For some of them, it was a way to provide greater backing to their decisions. However, for Navarrete, who had voted in favor of the permission, there was no need for such consultation. ${ }^{65}$

6o New additions were made some days later, on October 2, 1668. APSR, Ritos Chinos 35, Tom. 3, leg. 6, fols. 341r-342v.

61 "Apud sinas in signum reverentiae tegendum esse caput". BNCR, Ges. 1257.18, fols. 149r-154v. See also Bontinck, La Lutte Autour, 123, fn. 48. Ferrari wrote directly to the Superior General in October as did the French Jesuit François de Rougemont, SJ (16241676) and António Gouvea. Cummins, A Question of Rites, 156-157; Bontinck, La Lutte Autour, 124-125.

62 "An deceat et expediat Chistianos Sinas aperto capite Sacr interesse et Sacerdoti sacris operanti ministrare". BNCR, Ges. 1257.18, fols. 155r-161v.

63 The treatise by Santa María is called "Tratado sobre algunos puntos tocantes a esta missión de la gran China remitido desde esta ciudad de Cantón ar Mui Revdo. P. Luis de Gama de la Companía de Jesús, Visitador de las provincias eiusdem Societatis de Japón y China, residente en su Colegio de la ciudad de Macao. Por Fr. Antonio de Santa María, Prefecto Apostólico del Orden Seráphico de los Menores de la Regular Observancia en el sobre dicho reyno de la China". See Sinica Franciscana, vol. IX, 1019, fn. 3 and Sinica Franciscana, vol. II, 343 .

64 They were sent along with the authenticated memorials by Ferrari and Grelon.

65 He openly complains about those who did not accept the resolution about the head coverings. And argues that there had been other issues during the conference in which he did not agree but accepted because it was the decision of the majority. Fernández de Navarrete, Controversias, Trat. IV, fol. 225 r. 


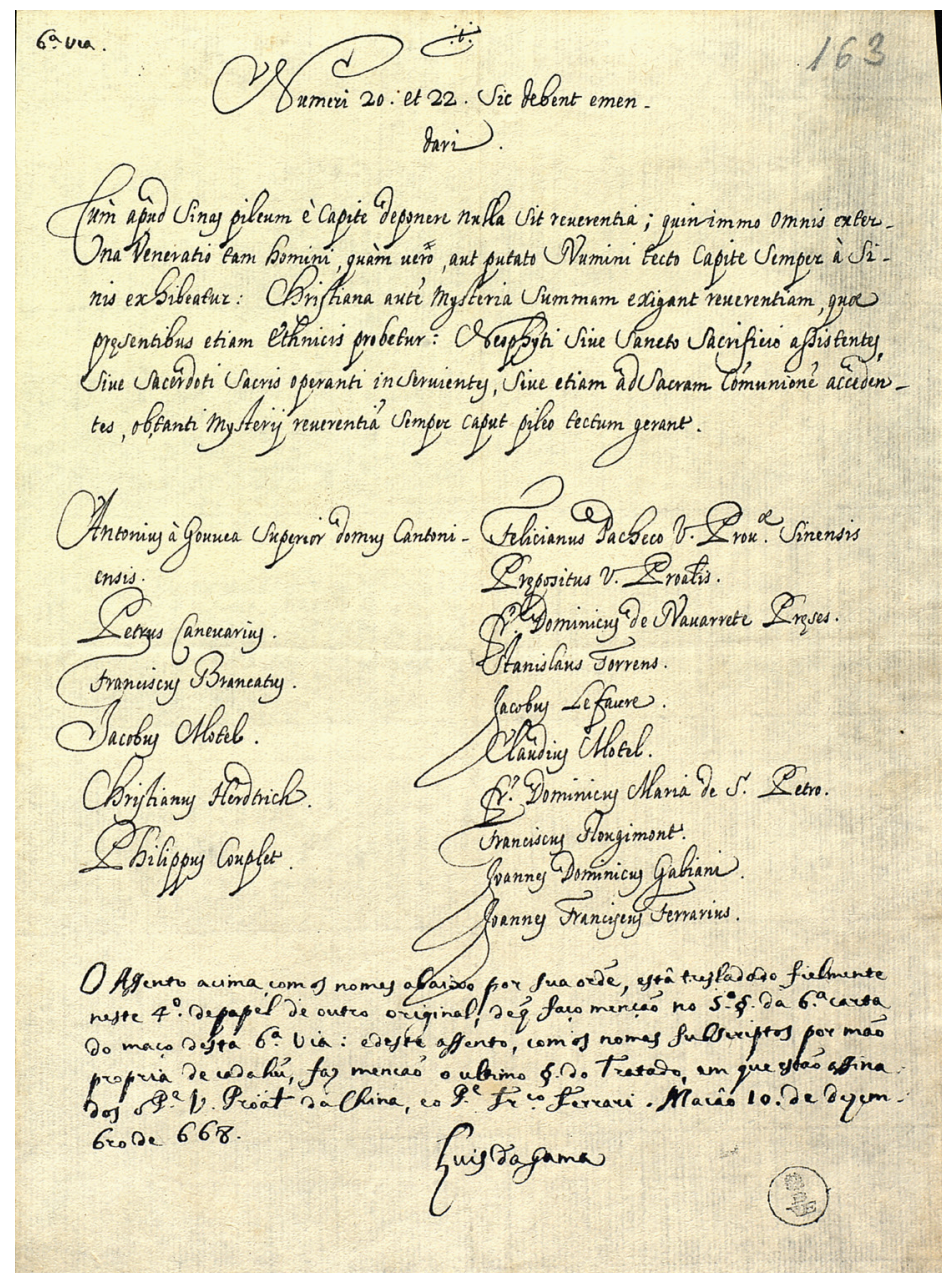

FIGURE 9.2 Agreement on the articles by fifteen missionaries at Canton and authentication by the Visitor Luís da Gama.

BNVE, GES. 1257.18, FOL. 163R

His acknowledgement that the decisions of the Canton conference did not necessarily require the approval of superiors reveals the missionaries' capacity to make norms for the mission in China. Each circumstance required a distinctive solution. In 1615, the Jesuits asked for a privilege when they found specific problems regarding head coverings in the performing of the Christian rituals in China. Decades later, in 1667, it was also the missionaries who decided to organize a conference that proved to be an effective instrument for regulating their praxis. 


\section{Two Positions, Multiple Authorities: Normative Claims in the Hat Controversy}

The question of the head coverings reveals the multiple actors participating in the normative order as well as the different procedures for deciding how to deal with practical issues in the mission such as attending mass. What should have been an uncontroversial issue, due to the papal decree of Paolo v, became the object of a heated controversy that generated new normative knowledge that drew on different sources of authority. This section explores the different normative sources-from canon law and moral theology to practical experience- that were mobilized during the discussions. This analysis shows how norms were justified based on different sources of authority without the preeminence of a specific one. In order to defend their own position, each group drew upon different legal rationales, and their performing of this conflict reflects their distinctive juridical agency.

\subsection{Natural Law versus Positive Divine Law}

When discussing the issue of head coverings, both in the case of converts and priests themselves, there were commonplace factors that determined their opinions. Missionaries were embedded with their own theological and juridical background and, naturally, they applied this knowledge to their discourses in order to defend their positions in the debate. Navarrete and most of the participants in the conference understood the practice of head covering as part of the positive law, constituted institutione hominum. To complete his argumentation, the Dominican followed St. Thomas Aquinas' views on the morality of human action, which distinguished the interior acts that correspond to the individual dispositions that accompany the performance of the exterior acts that can be expressed through words, signs, and actions. Among the external acts there were those corresponding to God, which were common to all nations, such as sacrifices, temples, and altars, and those indifferent actions that included, for instance, genuflections, the tilting of the head, or the bowing of the knee. Following Aquinas' argumentation, Navarrete highlighted how those external actions depended both on the object and the intention, so if man be the object of the action, it would be considered by Aquinas as "observance". ${ }^{66}$ This category characterized a type of worship within the doctrine of the Church and meant that there was no inconvenience to practicing

66 If God is the object of worship, it is called latria (theological term), if Church is the object, we refer to perdulia, if a saint is the object dubia, and if evil is the object idolatría. APSR, Ritos Chinos 35, Tom. 3, leg. 6, fol. 331r. 
reverences to other men, because it was compatible with the worship of God, the Church, and the saints. Uncovering your head would not be ex natura sua but ex hominum beneplacito et institutione, thus it would belong to the laws of nations. And the different manners of showing respect not only between members of different classes, but also among Christians themselves, proved it:

We see that the Jews and Turks worship the true God with their heads covered while we do it uncovered [...]. Among the Christians there are some religious people who kneel down and kiss the floor, others do not do that $[\ldots]$, some of us, Europeans, hear all mass on our knees while others sit $[\ldots]$, for a Dominican friar it would be dishonest to help while barefoot, while for a Recollect friar it would be if he wore shoes [...]. Even in the Church to worship God [...] sometimes they are depicted in Scripture on their knees [...], sometimes with their faces covered as in the case of the cherubs [...], sometimes 24 elders of Apocalypse are shown with the crown thrown at the foot of the Throne [...], sometimes standing or sitting. ${ }^{67}$

As can be seen, Navarrete beautifully enumerates dozens of examples to show the acceptance of variety in different traditions and faiths_-Yglesia non ita horret ceremonias gentilicas. In his discourse, following St. Jerome, he also highlighted the many traditions in the Roman Catholic Church that could be traced back to pagan rites, including fasting, the use of candles, the burning of incenses, and the offering of flowers and bouquets. Therefore, he asserted, it was possible to conclude that such diversity was accepted by the Church and there were not better or worse ceremonies, since the best ceremonies for a kingdom-China, in this case-were those chosen by its inhabitants. Consequently, Navarrete considered that for the mission these would be Chinese rites, and not those of Europeans. ${ }^{68}$

Fathers Grelon, Santa María, Lubelli, Manuel Jorge, Augery, Leonardo, and Valat, in their Respuestas, recognized that the best ceremonies for a particular kingdom were those created institutione hominum. However, they also judged that the best set of ordinances for divine worship were those of canon law and not those derived from the law of nations. The Church was governed by the Holy Spirit, so not only did this mean that it had the capacity to select the most appropriate ceremony, but also that the Holy Spirit "enhances and elevates it

67 APSR, Ritos Chinos 35, Tom. 3, leg. 6, fols. 331v-332r.

68 "Dudas", APSR, Ritos Chinos 35, Tom. 3, leg. 6, fols. 332r-332v. 


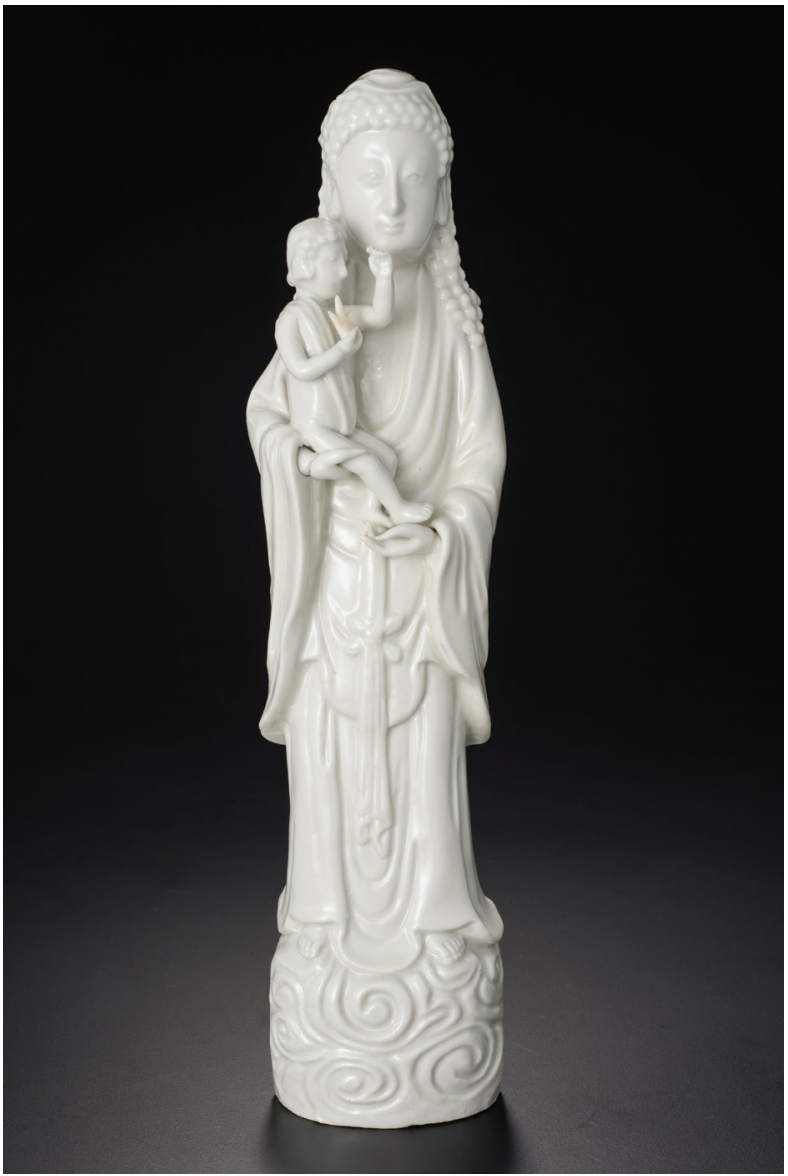

FIGURE 9.3

Figure of Madonna and child, c. 169o, Kangxi period, Qing dynasty. COLLECTION OF THE ASIAN CIVILISATIONS MUSEUM, SINGAPORE

[the ceremony] to a different level, making it more excellent",69 as happened with the woods and metals used to build a church's roof, which could thereafter never be reutilized for non-sacred purposes.

It appears that Navarrete could say little to the argument about the primacy of canon law, so the Dominican opted to refer in his answer to the case of women, which remained a case of high controversy in the Chinese mission. Chinese Christian women used to wear a veil at the time of confession, as can be seen in the statuette of the Madonna and child (Figure 9.3). ${ }^{70}$

69 "Respuestas", APSR, Ritos Chinos 35, Tom. 3, leg. 6, fol. 325v.

70 In fact, missionaries approved in article 19 the obligation to wear a veil or something similar between the priest and the penitent: In mulierum confessionibus audiendis interponaturvelum, seu aliquid aliud inter Sacerdote, et penitentem. Cicé, Acta Canthoniensia, 26. See also Menegon, "Deliver us from Evil", 36. 
This delicate porcelain, depicting a fine Christian veil worn over the traditional Buddhist curly hair of the Virgin, was probably used by the missionaries to strengthen the faith of the natives. However, Navarrete argued that Christian women in China attended mass uncovered, following their ordinary practice to pay respect to their superiors and Gods in this way. St. Paul the Apostle had given women the directive to pray with their heads covered (1Cor 11:3-9) so the Dominican asked, with a rhetorical flourish, why his opponents did not criticize that practice too. He posed the question directly: should the missionaries not be able to also introduce this regulation in China? ${ }^{71}$

Navarrete further argued that the custom of covering the head to show respect was, in fact, in accordance with Roman Church law because it was granted by the brief of Paolo $\mathrm{V}$ mentioned earlier. He considered it a reasonable petition by the old missionaries and that there would be no benefit in having it overturned. For him, it was good to maintain honest and virtuous habits and prevent conflicts. Otherwise, the missionaries ran the risk of hurting Chinese pride. ${ }^{72}$ In addition, he believed that the Pope's decisions to uphold Chinese Christians' rites and to not seek uniformity should not be questioned. ${ }^{73}$ Political conditions were also important because, at any time, the Chinese could wrest power from the Tartars and the status of the Christian missions could suddenly change. ${ }^{74}$

In response, the other group outlined that the need to ask the Pope for a privilege was precisely the most evident manifestation of the preeminence of the Church's regulation over the law of nations. They also suggested that the Pauline privilege did not exist and, even so, it would no longer reflect the Pope's will, since the circumstances had changed. From their point of view, the barriers that had made such a concession necessary in 1615 no longer existed in 1668. Thus, although they were in fact confined in Guangzhou, they thought that changing the hat regulation would not have any negative effects on Christianity from the Chinese authorities because they were convinced that it was not such a serious offense for the Chinese. For the group of the Respuestas, it was a privilege used without need. By contrast, they demanded the privilege be reserved for women because, in that case, there was still an evident difficulty in trying to introduce the European tradition. The missionaries ultimately had

\footnotetext{
71 Fernández de Navarrete, Controversias, Trat. IV, fol. $222 \mathrm{r}$.

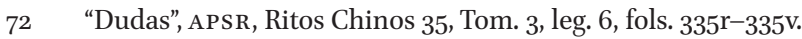

73 "Dudas", APSR, Ritos Chinos 35, Tom. 3, leg. 6, fols. 325v, 336r.

74 "Dudas", APs R, Ritos Chinos 35, Tom. 3, leg. 6, fol. $335 \mathrm{v}$.
} 
the duty to incorporate Roman ceremonies whenever there was a chance, and therefore had to persist and lead by example, they argued..$^{75}$

Though Navarrete agreed with this last point, he thought the right moment was yet to come:

Although it is good and admirable to gradually introduce the customs of the Roman Church into the missions [...] it is necessary to wait for the right moment and for the Law of the Lord to have firm roots. ${ }^{76}$

The need to gain the favor of the natives was one of the main reasons for Navarrete's insistence on adapting Christian ceremonies to the Chinese tradition. Quoting Aquinas, Christ's actions, Cardinal Lugo, and the historian Henri de Sponde, among others, he explained the need to respect the Chinese traditions that went back thousands of years. ${ }^{77}$ However, in their Respuestas, Grelon and the like denied rejecting local rites and ceremonies. On the contrary, they accepted the Chinese dress style, paid their visits following local etiquette, and sat in the Chinese way. Furthermore, in their opinion, their brothers were overreacting about the matter of the cap. From their point of view, Chinese Christians were aware that Catholicism, like other religions, had its own rules. It was even usual during evangelization that Chinese natives asked to learn the rules they had to follow before converting, meaning that the "right moment" had already arrived.

\subsection{Moral Theology in the Chinese Mission}

One of the most heated arguments occurred about the Chinese Christian practice of being bareheaded during confession, as was common for criminals in China when condemned for their crimes (Figure 9.4). ${ }^{78}$ This practice was added by the Jesuit fathers of the early mission; the reasoning behind this was that penitents at confession took on the role of convicts and sinners. Otherwise, throughout mass and Eucharist they had permission to be covered again, following what was for them the Chinese manner too. During these acts, the faithful were in a state of grace before God and they acted as guests at Christ's table, accepted as friends, brothers, and disciples, but not as sinners.

\footnotetext{
75 "Respuestas", APSR, Ritos Chinos 35, Tom. 3, leg. 6, fols. 326r-326v.

76 "Aunque es bueno y loable el ir introduciendo en las misiones nuevas las costumbres de la iglesia romana [...] es necesario aguardar a tiempo oportuno y a que tenga raíces firmes la ley del señor". "Dudas”, APSR, Ritos Chinos 35, Tom. 3, leg. 6, fols. 335v-336r.

77 "Dudas", APSR, Ritos Chinos 35, Tom. 3, leg. 6, fol. 334v.

78 For the rite of sacramental confession, see Menegon, "Deliver us from Evil", 34-46.
} 


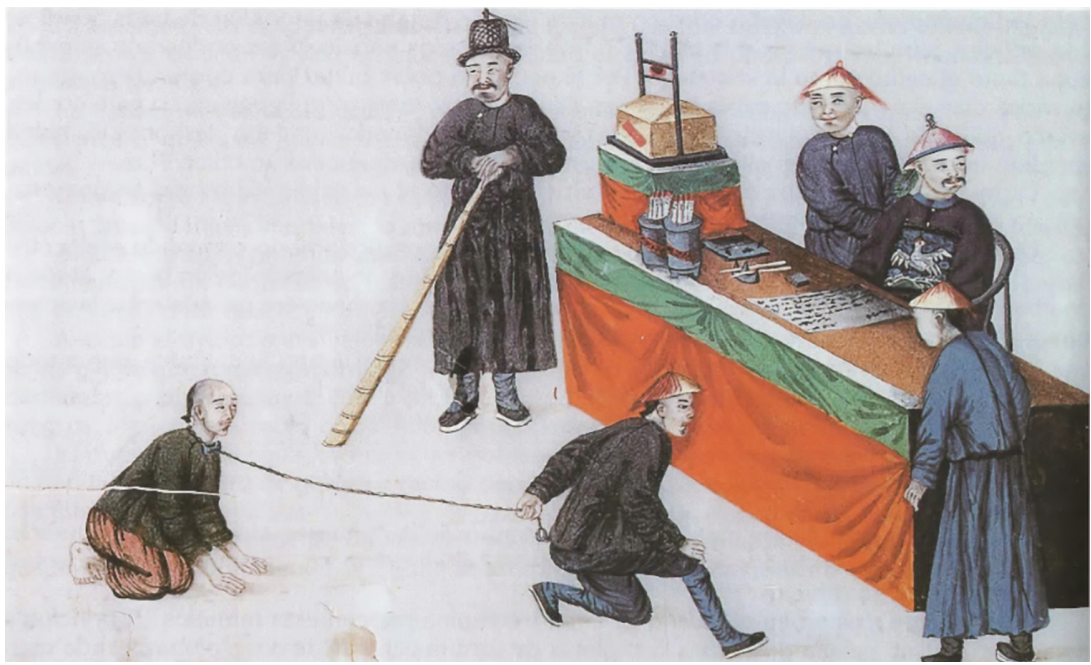

FIGURE 9.4 "Trial before the Court". Gouache by anonymous author. Canton, c. 186o. Real Colegio PP. Agustinos (Valladolid). COURTESY OF THE MUSEO ORIENTAL DE VALLADOLID

In his Dudas, Navarrete defended the appropriateness of this old practice in the Chinese mission. From his point of view, Roman tradition perceived the confessional as a court of justice, the confessor as a judge, and the penitent as an offender (reo). And, in his opinion, getting the Chinese to remove their hats was the perfect act to make them feel as if they were in a court of justice. The Dominican elaborated:

the cap is taken off in the way the habit is taken off a knight before slaughtering him, which is felt like death itself to him. The Chinese feels the same while removing his cap. For that reason, he is ordered to go uncovered to confess. ${ }^{79}$

The Franciscan Santa María and the ones who signed the Respuestas countered this position by stressing that Christians were permanent sinners and condemned under God's law, not only during confession. Thus, they should be bareheaded during mass, Eucharist, and confession.

As Figure 9.5 shows, they considered two different hypotheses, after having heard the reasoning of Navarrete and their opponents, to elaborate their argument. They first appealed to the role of the believer: Since they all agreed upon the condition of sinners as reos in confession (1a), Santa María 


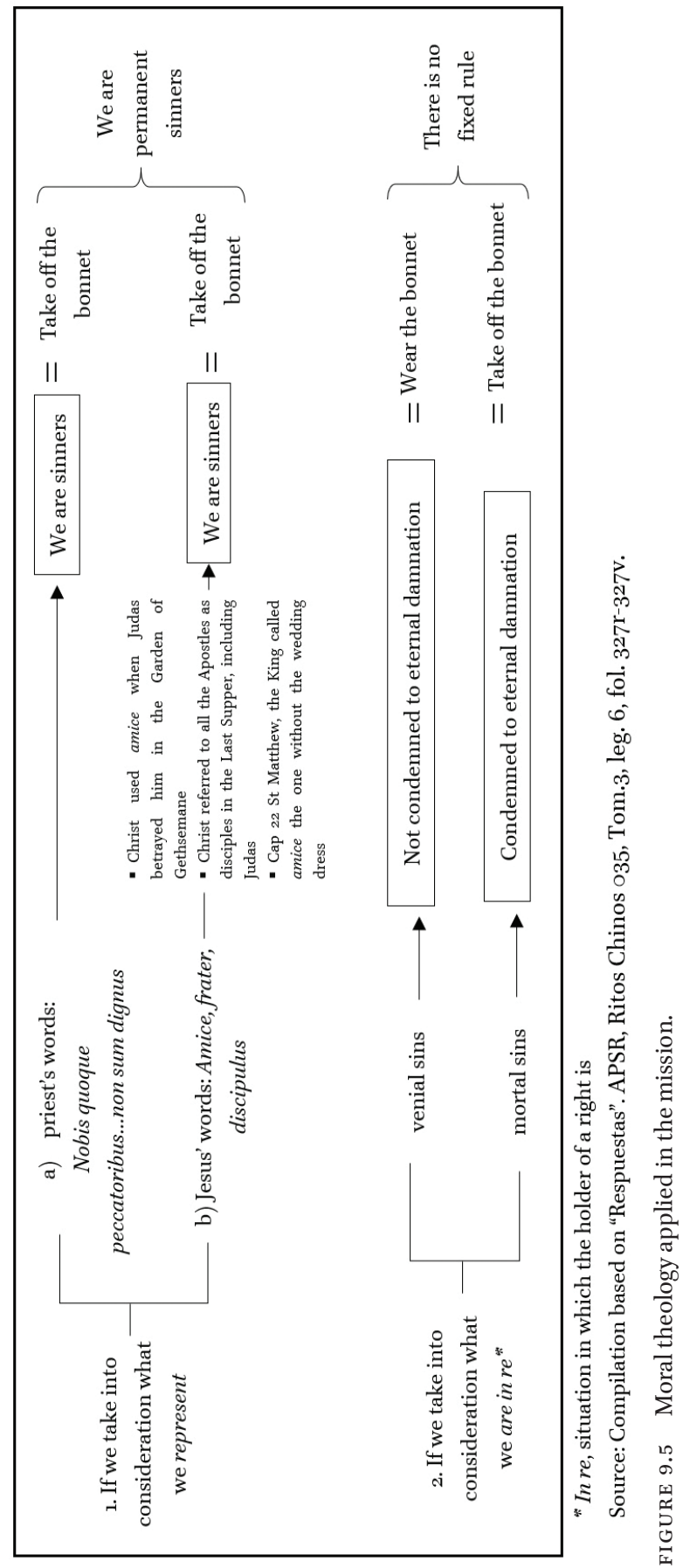


used several biblical examples (mainly of Judas) to show that during mass and communion they were also reos (1b). Second, they introduced the categorization of sins according to categories of classic medieval theology and demonstrated that a Christian would not always be punished to eternal damnation and be considered a reo (2). The outcome would depend on the type of sin the penitent had committed. Following this reasoning there was no fixed rule to follow. Moreover, the sinner could also be in a state of sin not only during confession, but also during mass; and those in confession could have committed mortal or venial sins. If one extended this logic, Christians should be uncovered or covered regardless of the time of the ritual. At this point, it is of note that the supposedly most conservative group that wanted to implement the "European style" was in fact proposing a more adaptative stance than the ones who defended Chinese customs. In China, only those condemned to the death penalty appeared bareheaded. And, from the point of view of the authors of the Respuestas, Navarrete and his allies were demanding to follow Chinese judicial rules without realizing that during confession not all penitents were condemned to eternal damnation.

\subsection{Chinese Customs and Uses as Seen by the Missionaries}

The significance for the Chinese of the uncovered head was at the heart of the dispute. Thus, the missionaries' perception of the relevance of the hat is fundamental to understanding the different positions adopted by each group. In the discussion, both groups of missionaries affirmed their respect of Chinese etiquette and culture. In fact, what was put into question was the gravity of the rule concerning head coverings for the Chinese. The conflict arose because each group had different views regarding the importance of this rule for the Chinese. While Navarrete and those supporting him thought that being covered was a central expression of humility for the Chinese, the group of the Respuestas believed that this practice was not as important as their opponents judged and, consequently, Chinese Christians could be bareheaded, i.e., the custom could be changed.

There are two examples which illustrate that the missionaries' understanding of Chinese culture was a key element that influenced their positioning in the debate. The first one is the dynastic change in 1644. For the group of the Respuestas, which were in favor of changing the custom of being covered during Christian rituals, the regulation of hats was not considered a long-standing custom in China since it could be changed by dynastic precept. The 17 th century saw a change in the imperial dynasty when the Manchu made their way to Beijing. As a result, new styles and customs were implemented, 
although characteristics of the Ming era were maintained during the Qing era. Santa María and his allies affirmed:

We see that they are not tied to the enforcement of the rules except when it suits them not to use them. Rather, the Chinese show off their resemblance to the Tartars in being cruel, in removing their beards (something they valued greatly before), and this also affects the Chinese mandarins who sit on the ground without their bonnets and other such examples that are well-known. ${ }^{80}$

For Navarrete, by contrast, it was unquestionable that the Chinese custom was still in use despite the changes in the headwear that accompanied the change of dynasty. He thought his opponent's argumentation was invalid because they were referring to rural areas of China instead of observing the etiquette of the cities and in court. From his point of view, state rituals and worship to heaven and earth as well as to ancestors and other types of deities, such as Ching Hoan (城隍神 Chenghuangshen, City God) had been part of Chinese ritual life since ancient times and the Manchus accepted the Confucian canon as the foundation of their power. Inferior to superior, disciple to master, son to father-all showed their respect invariably with their heads covered. And the Dominican affirmed that the Qing emperors did not change these rites. ${ }^{81}$ In his defense, he even considered that the native Christians' ceremonies were perhaps more civilized than those of Europeans. While hatless Europeans partially bowed the knee to show respect-sometimes to the ground-or the most zealous kneeled fully, the Chinese made their prostration with their head touching the ground three or four times- the so-called 吒頭 koutou. ${ }^{82}$

Navarrete further argued that civility in China was related to the use of a head covering. He based his arguments on his own experience and the reading of "their books", as the following paragraph shows:

In one [book] it is said that the beginning and origin of reverence is the cap on the head. In another [book] it is said that man is not a man if the ceremony of putting the cap on his head is removed [...]. And so, a poor villager, broken and barefoot but with a cap, would make courtesy to his emperor without anyone noticing. However, if he would have footwear

\footnotetext{
8 o "Respuestas", APSR, Ritos Chinos 35, Tom. 3, leg. 6, fol. 325r.

81 "Dudas", APSR, Ritos Chinos 35, Tom. 3, leg. 6, fols. 333r-333v.

82 "Dudas", APSR, Ritos Chinos 35, Tom. 3, leg. 6, fol. 338v.
} 
and be well-dressed but without a cap, he would not dare show courtesy, and no one would forgive him for his rudeness. ${ }^{83}$

Both sides thus defended the need to respect Chinese tradition. The difficulty lay in understanding to what extent the enforcement of a rule on head coverings confronted a central value of Chinese tradition. The consequences of the dynastic change were interpreted differently by each side, resulting in new arguments that needed to be exposed.

One of the most powerful tools employed by theologians in the early modern period involved the use of analogy. To defend the imposition of a new rule for the Chinese natives and the priests in China, the authors of the Respuestas compared the case of the hats with the Muslim tradition of going barefoot into their mosques in China. This group claimed that this tradition was accepted in the Chinese empire without difficulty. And they included an excerpt (traslado) in their text bearing testimony to this special practice in the Chinese empire:

According to the custom of the Moors in China [...] when they go to pai [ 拜 bai, worship] our Lord or a God (who they do not believe to be triune and only one being without dislocation of people), when entering the mosque called pai ly, where they have hung the letter ii [ $-y i$, one] [...] and silks, everyone takes off their shoes when entering in reverence etc. The numerous Moors of Nankin wear white bonnets in the streets, cut their mustaches following the style of their bad sect $[\ldots]$ and keep the rites and ceremonies of their law. ${ }^{84}$

The people known as Moors at the time appeared to have introduced their own practices on Chinese soil without difficulty and Grelon and his allies questioned why this was not possible for Catholicism. In his response, Navarrete reminded his confreres of Islam's deeper roots in China compared to Christianity's. In his counterarguments he also made a direct attack arguing that the permission for Muslims to go barefoot was simply because they had bribed the Chinese authorities. In a tongue-in-cheek tone, the friar even challenged his opponents to raise enough silver from New Spain and Tierra Firme to try a similar bribe. He ironically guaranteed them that by paying a lot of money to Chinese authorities being uncovered would become a new tradition in the Chinese mission. Moreover, he risked declaring that those converting to Islam were not in fact Chinese but relatives from the same Muslim family — in other

83 "Dudas", APSr, Ritos Chinos 35, Tom. 3, leg. 6, fol. 338r.

84 "Respuestas", APSR, Ritos Chinos 35, Tom. 3, leg. 6, fols. 329r-329v. 
words, foreigners - or even those who were Chinese and who eventually apostatized, so would be classified by Navarrete as "not pure Chinese". 85

Navarrete also did not waste the opportunity to criticize his counterpart's arguments. From his point of view, they were comparing two unrelated realities; instead, they should have compared the use of the hat in both traditions-Islamic and Chinese. In fact, Muslims allowed their converts to remain covered in their mosques because, Navarrete insisted, the most important manifestation of courteousness in China was related to the use of the hat and not with being barefoot. ${ }^{86}$ This would mean that new customs that did not contradict long-standing traditions could be observed; new rules contra-consuetudo could not.

\subsection{The Importance of Experience in the Missionary Field}

Experience in the missionary field also played its part in the hat controversy. Each member that took part in the conference had worked in a different province, sometimes in more than one, and for a different amount of time, and all of them brought that experience to the debate. On the one hand, Father Adrien Grelon and his companions, who were in favor of changing the custom of being covered in the Christian mission, declared in his Respuestas that there were already several places in China in which Christians attended mass, took communion, and prayed bareheaded without any disturbance. They named the province of Shandong where both Santa María and Jean Valat had their residence. ${ }^{87}$ The Beijing mission, led by Father Schall, was also used as an example. His authority made this case particularly valuable in supporting their position since he was publicly recognized as the most experienced person of the Chinese mission at that time. ${ }^{88}$

Grelon, Santa María, and the others who signed the Respuestas presented other significant examples to demonstrate that the Chinese were not as strict about hats as their brothers suggested. The missionaries went to the emperor's court years earlier and visited the 禮部 Libu (Board of Rites), the most

\footnotetext{
85 "Respuestas", APSR, Ritos Chinos 35, Tom. 3, leg. 6, fol. 33or.

86 "Dudas", APSR, Ritos Chinos 35, Tom. 3, leg. 6, fols. 337v-338r.

87 "Respuestas", APSR, Ritos Chinos 35, Tom. 3, leg. 6, fol. 325r. Grelon in other letter on June 1668 says: "E pera não dissimular nada, ainda que sempre houve e inda hoje há alguns christãos que ouvem a missa cubertos, com tudo a maior parte a ouvem descubertos, e com tudo ate agora nunca se vio que os Padres mandassem aos que estavão desscubertos que se cobrissem, se não por ventura em Ch'ang-shu aonde disem que o P. Rougemont o mandou a seus christãos que ate então tinhão sempre usado o contrario". Margiotti, Alcuni problemi, $3^{2-33} \mathrm{fn} .113$.

88 Sinica Franciscana, vol. IX, 1023.
} 
important institution in the empire that oversaw all state and secular ceremonies, rituals, and sacrifices. To their surprise, officials were not wearing hats. ${ }^{89}$

Santa María also recalled the case of the Italian Prospero Intorcetta. The significance of this case for the group of the Respuestas came from the fact that Intorcetta was actually in favor of using the hat but later changed his mind, opting to follow "European style" despite his first inclination to follow "Chinese etiquette". He came to this conclusion because he had decided to solve the question of the hat in his mission by following his own method. According to Santa María's account, Intorcetta, having observed the lack of uniformity in his church, gave the parishioners the possibility to decide among themselves whether to use the hat or not. The believers opted not to wear the hat because they considered it the most honorable way to show their respect, so he too decided to follow their wishes..$^{90}$ In this case, we can clearly observe how Santa María and his group, by adding the example of Intorcetta, mobilized the customary law argument: Intorcetta was a newcomer and ignored Chinese etiquette when he first arrived in the mission so that Europeans also had to learn Chinese customs through their parishioners. In the words of Santa María, "they know much better, as Chinese natives, than us, foreigners, the political and religious reverence in this kingdom whatever it may be". ${ }^{11}$ The vindication of this custom involved the recognition of Chinese agency. Santa María solidly affirmed that Chinese commoners and "mandarins" would have openly shown their disagreement in case of any objection and, therefore, it was not such a show of serious disrespect to appear bareheaded. ${ }^{92}$

In his response, Navarrete argued that neither Christians in Beijing nor Father Schall would ever dare to visit the imperial apartments without wearing the proper hat. Importantly, though it was true that imperial officials were bareheaded in the Libu, there were two situations when this was possible. First, it was commonplace that they took their hats off in the summer, but they always asked for permission before doing so. Second, removing one's hat was a clear sign of disrespect to and disregard for the missionaries as prisoners. ${ }^{93}$ Navarrete additionally gave several examples of his experiences, including his visit to the 兵部 Bingbu (Board of War) and the missionaries' visit to the authorities of Guangzhou during their confinement. But, although he answered by referring to his own experiences, in Navarrete's opinion, the anecdote of the visit to

\footnotetext{
89 "Respuestas", APSR, Ritos Chinos 35, Tom. 3, leg. 6, fol. $324 \mathrm{~V}$.

$90 \quad$ "Respuestas", APSR, Ritos Chinos 35, Tom. 3, leg. 6, fol. 325r.

91 Sinica Franciscana, vol. IX, 1023.

92 "Respuestas", APSR, Ritos Chinos 35, Tom. 3, leg. 6, fol. 325r.

93 "Dudas", APsR, Ritos Chinos 35, Tom. 3, leg. 6, fols. 334r-334v.
} 
the Libu and the few examples presented by the authors of the Respuestas were not valid as evidence since they did not provide a reliable representation of the traditions of such a vast empire.

As shown, the missionaries included several types of examples in their discourses. Their selection depended on different factors, mainly based on the degree of credibility of the referred person or group. Chinese Christians, as natives, provided authority, while Schall, working in the capital for the imperial court, also added value to the debate. In the discussions, there was also a minor tussle between the two groups regarding the authority of the old missionaries over the new generations. While Navarrete vindicated the importance of age for a more accurate opinion and educated judgment, his adversaries did not have the same opinion. They considered it was not necessary to have many years of experience in the mission, nor to be old, to have a proper perception of Chinese reality. In their response, they swiftly replied: "You should not state 'I did not see therefore it does not exist' [...]. There is no need of many years nor to be old to experience and verify what is happening [...]. It is neither a question of antiquity nor related to past". 94

When the ages of the missionaries and their years of experience in the Chinese mission together with their votes are analyzed, however, one can reach two conclusions. First, regarding age, the average age of both groups was almost the same ( 52 for the authors of the Respuestas who voted for the implementation of the "European style" of being uncovered and 54 for the ones who favored the "Chinese style" of being covered). Thus, it does not seem that there were any significant differences relating to age that affected voting on the regulation of the hat. Second, the average years of experience was 14 for the Respuestas group and 23 for the others. Aside from Santa María, who was one of the oldest and most experienced men - he was 66 years old in 1668-the most experienced men in the mission were most in favor of letting the Chinese wear their hats during mass and maintaining the use of the papal privilege conceded to the Jesuits decades before. ${ }^{95}$

94 "No se signe no lo vi luego no lo ay, ni porque sean antiguos y viejos, porque para ver esto no son menester muchos años, ni es menester ser viejo porque es cosa presente que no es menester muchos años para experimentar y palpar en las manos, no es cosa antigua ni pasada". "Respuestas", APSR, Ritos Chinos 35, Tom. 3, leg. 6, fol. 33or.

Average age (in 1668) is based on the information of "Anexo" in Esquivel, El confinamiento de los misioneros, 367. Average years of experience (in 1666) in the mission is based on Esquivel, El confinamiento de los misioneros, 237; Dehergne, Répertoire des Jésuites and Busquets, "La formación y los recursos", 5 . 


\section{Conclusions}

In addition to their obvious religious role, historians have analyzed the part of missionaries in China as political agents, intellectuals, ethnographers, translators, and ambassadors. Yet little has been written about their role as lawmakers. In this chapter, the Canton exile has proven to be a unique moment in the history of Christianity in China that attests to the missionaries' active participation in the regulation of their own praxis and that of their parishioners.

The need for a coherent, standardized, and centralized set of rules in the mission resulted in an exceptional meeting in the history of the early Chinese mission. Missionaries from three different religious orders of six different nationalities and subjected to different jurisdictions held a conference to negotiate the rules for pastoral activity in the Chinese mission. They also set up the conditions for the meeting and reached their own resolutions for the conflict in the missionary field that would be later confirmed by their superiors. The Acta Canthoniensia was the outcome of this important event that decisively changed the practice in the missions over the subsequent decades. ${ }^{96}$

In their formulation of arguments, both groups searched a corpus of norms for authority to construct new rules. Sources reveal that practical conditions were an essential element that explained their position in the debate. Moreover, the creation of new norms also involved the need to observe Chinese customs alongside a process of learning about Chinese culture. Their knowledge about Chinese etiquette and its importance for Chinese natives also played a major role in the debate. Missionaries transformed into anthropologists, rendering accounts of their observations influenced by their readings and exchanges. And their accumulated knowledge was also influenced by their own experiences which became a source of authority in the debate. The missionaries' ability to argue effectively was also affected by their theological-juridical background imbued with Tridentine policy and their capacity to apply moral theology to the case of the hats.

Together, these aspects helped them produce a new discourse composed of a variety of elements that resulted in a new normative order. The missionaries regularly invoked the Fathers of the Church-St. Augustin and St. Jerome-as well as passages from the Bible, and the names of Aquinas, St. Paul, the Cardinal Lugo, and the theologian, philosopher, and jurist Francisco Súarez resonate throughout their discourses. But, simultaneously, their vision was embedded 
in the Chinese context. Not only did they consult Chinese classical books to be informed about the underlying meanings of Chinese rites and practices, but they also directly sought the opinion of Chinese converts to back up their arguments and counted on their own experience in the field to add legitimacy to their opinions.

Moreover, concerning the question of the hat, context is one fundamental element that runs through the debate; the conference was favored by the situation of Christianity at the time. Although the capital of Beijing fell in 1644 and the Ming dynasty collapsed that year, the definitive unification of China under the Manchus took almost another four decades. Chinese society faced important changes not only because of the dynastic change, but also in their economic and social system, and missionaries understood the uniqueness of this moment. However, each group had a different opinion about it. Some saw this moment as an opportunity to renegotiate old models and norms, while Navarrete and his companions claimed for the need to retain imperial favor and wait for stability in the future. The position of Catholics in China was that of subordination and the creation of new norms was inevitably influenced by the asymmetrical relationship between the European and Chinese; Europeans were foreigners on Chinese soil and the Chinese empire was respected and admired by many of them. In their arguments, Navarrete's side even defended the superiority of Chinese etiquette relating to administration, politics, and order. These clear facts led to more pragmatic argumentations that moved away from rigid orthodoxy. In their discourse, missionaries moved swiftly between what was tactically more advantageous to what was morally superior, and mobilized these different argumentations depending on their interest in defending one position or the other. And religious groups that were supposed to be allied — as in the case of members of the same religious orders-openly adopted different approaches regardless of their religious adscription.

The analysis of the sources has shown that the missionaries' discourses were not part of a simple debate based on the classical dichotomy of either adapting or not adapting to Chinese culture. Missionaries were not simply failed importers of Church law or successful practitioners of it. Although in the debate there were two different positions-incorporating the tradition of being bareheaded or keeping the custom of being covered as decided by the Jesuits in their arrival to the mission - their narratives represented their common effort to accommodate Church law. In this public representation, they made use of different elements to provide legitimacy that not only drew from the Roman tradition but from a large reservoir of norms that went far back in time and were tied to how missionaries reconstructed both the European and the Chinese past. 


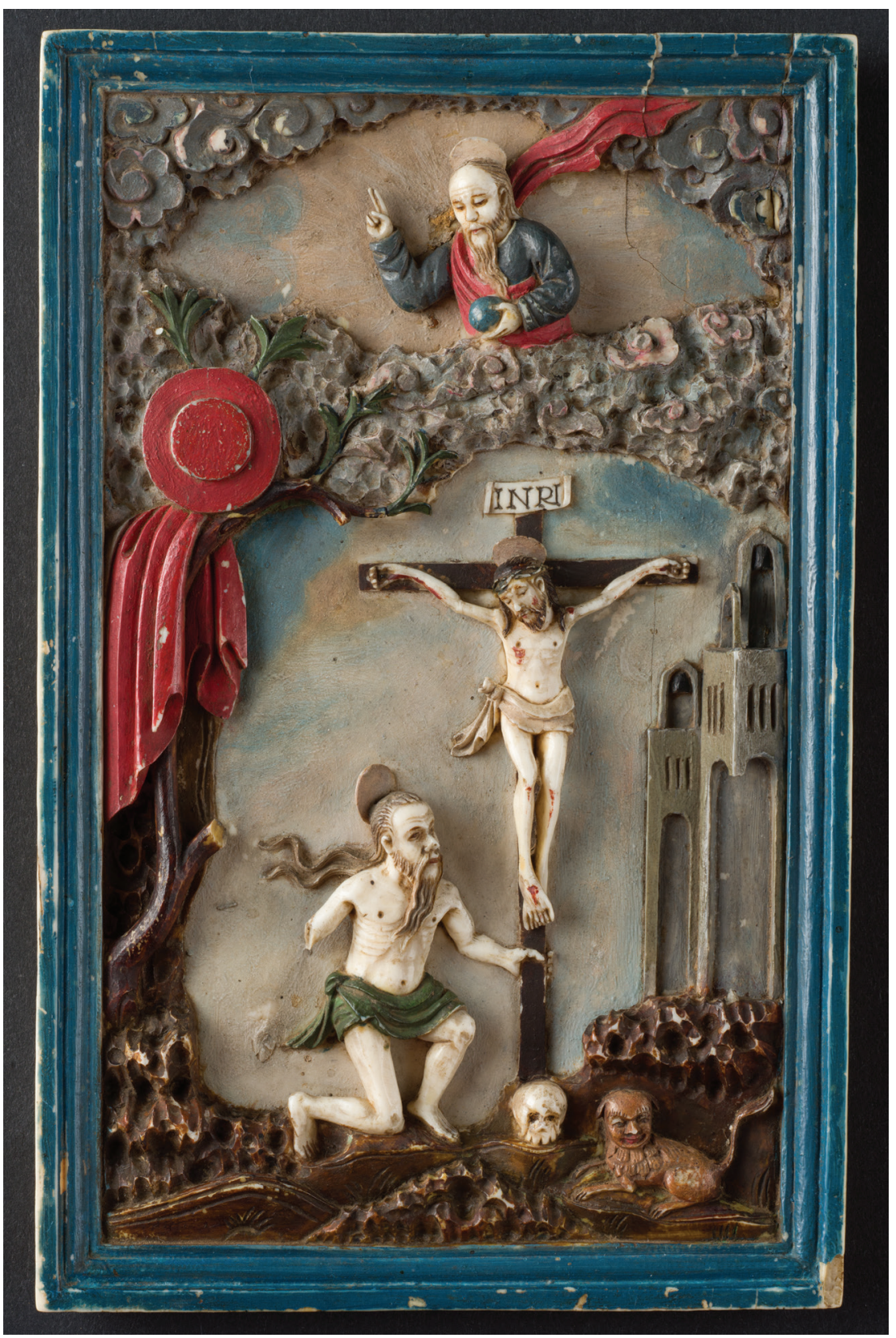

FIGURE 9.6 Painted ivory panel of St. Jerome praying before the crucified Christ. Southern China. 17th Century. COLLECTION OF THE ASIAN CIVILISATIONS MUSEUM, SINGAPORE 
In the missionary field a great decisional pluralism can be found, and the dynamic tension between the Tridentine Church and the Missional Church appears to converge on a complex reality. In this performance that takes place very far from the center of powers in Europe, subjects that are apparently passive agents in the process of law making become relevant agents capable of producing new normative outcomes.

The hat controversy exemplifies a case of norm-production in which all missionaries drew upon both Chinese and European traditions but also the different currents within them depending on their practical needs. The Canton Conference resulted in a hybrid reality in which the Chinese were permitted to be covered during mass, the priests continued using the 祭巾 Jijin, and the Roman Orthodoxy was also present. As can be seen in the painted ivory panel of St. Jerome praying before the crucified Christ (Figure 9.6), God Father is engraved in the image with the top of the head shaved following the Tartar style. Yet, he is not alone. The Tridentine Church makes its appearance, on the left, with the red hat representing the Roman Curia. As in this visual representation, Chinese and European traditions came together in the missionary field and gave shape to a new policy to guide missionaries and Chinese Christians in their path of evangelization over the next decades.

\section{Acknowledgements}

I would like to thank Isabel Murta Pina, Tomás A. Mantecón Movellán, Jorge Díaz Ceballos, Anna Busquets Alemany, Diego Sola, the editor of this book, and the two anonymous reviewers for their assistance with this contribution. I would also like to thank Ricardo Martínez Esquivel for delivering a copy of his doctoral thesis to me. This research is part of the project "Gobernanza, conflicto y construcción de cultura política en la Edad Moderna" (MICINN-FEDER/ UE, PGC2018-093841-B-C32) and RESISTANCE: Rebellion and Resistance in the Iberian Empire, 16th-19th centuries (H2O2O-MSCA-RISE-2017 No.778076). Unless otherwise stated, all translations and errors are mine.

\section{Bibliography}

\section{Manuscripts}

Archives of the Santo Tomás Convent (APSR, Avila, Spain); "Respuestas a unas objeciones de las cortesías de los bonetes de China \& ${ }^{a}$ firmado por varios PP. en la 
reclusión de Canton (incluido el vP. Fr. Antonio de Sta. María)". Sección Ritos Chinos o35. Tomo 3, Tratados misceláneos $(1637,1669,1717)$, Carpeta 6, fols. 324v-33ov.

Archives of the Santo Tomás Convent (APSR, Avila, Spain); "Dudase si en China es conveniente que asistan los cristianos a la misa cubierta la cabeza”, Sección Ritos Chinos o35, Tomo 3, Tratados misceláneos $(1637,1669,1717)$, Carpeta 6, fols. 331r-342v.

Archives of the Santo Tomás Convent (APSR, Avila, Spain); "Desmiéntese el P. Sarpetri con el testimonio de los PP. Balat y Grelon, de la Comp. De Jesus”, Sección Ritos Chinos o35, Tomo 3, Tratados misceláneos (1637, 1669, 1717), Carpeta 6, fols. $324 \mathrm{r}-324 \mathrm{~V}$.

Roman Jesuit Archives (ARSI, Rome, Italy); "Praxes quadam a Missionariis Dominicains, Franciscan ac Societatis Iesu in Sinica Mission observandae: 1668", Fondo Gesuitico, 722-12, fols. $1 \mathrm{r}-4 \mathrm{r}$.

Rome National Central Library (BNCR, Rome, Italy); "Apud sinas in signum reverentiae tegendum esse caput", Ges, 1257.18, fols. 149r-154v.

Rome National Central Library (BNCR, Rome, Italy); "An deceat et expediat Chistianos Sinas aperto capite Sacr interesse et Sacerdoti sacris operanti ministrare", Ges 1257.18 , fols. $155^{\mathrm{r}-161 \mathrm{v} \text {. }}$

\section{Printed Sources}

Cicé, Louis de, Acta Cantoniensia authentica. In quibus praxis missionariorum Sinensium Societatis Jesu circa ritus Sinenses approbata est communi consensus partum Dominicanorum, \& Jesuitarum, qui errant in China; atque illorum subscription firmata. Nunc primum prodeunt transmissa ex Archivio Romano Societatis Jesu, cum accessioni Epistolae, Rome 1700: Gesuiti-Collegio Romano.

Collectanea S. Congregationis de Propaganda Fide Seu decreta instructiones rescripta pro apostolicis missionibus, 2 vols., Rome 1866: Ex Typographia Polyglota.

Fernández de Navarrete, Domingo, An account of the empire of China; historical, political, moral and religious. A short description of that empire, and notable examples of its emperors and ministers. Also, an ample relation of many remarkable passages, and things worth observing in other kingdoms, and several voyages. There are added, the decrees of popes, and propositions defined at Rome for the mission of China; and a bull of ... Clement X., in favour of the missioners. London 1732: H. Lintot.

Fernández de Navarrete, Domingo, Tratados Historicos, Politicos, Ethicos, y religiosos de la Monarchia de China. Descripcion breve de aquel imperio, y exemplos raros de emperadores y magistrados del. Con narración difusa de varios sucesos y cosas singulares de otros reynos, y diferentes navegaciones..., Madrid 1670: Juan García Infançon.

Fernández de Navarrete, Domingo, Controversias antiguas y modernas entre los Misionarios de la gran China. Repartidas en nueve tratados con lo que toca al culto y 
veneracion quel chino da a su maestro Confucio y a sus progenitores difuntos con respuesta á diversos tratados de los Pes. Dela Compañía de Jesus, Madrid 1679.

Sínica Franciscana. Relationes et Epistolas Fratrum Minorum saeculi XVI et XVII collegit, ad fidem codicum redegit et anotavit P. Anastasius Van den Wyngaert OFM, Vol. II, Firenze 1942: Ad Claras Aquas.

Sinica Franciscana. Relationes et Epistolas Fratrum Minorum Fratum Minorum Hispanorum in Sinis qui annis 1697-98 missionem ingress sunt collegit, ad fidem codicum redegit et anotavit $\mathrm{P}$. Fortunatus Margiotti, OFM, editionem autem prasentem praeparaverunt et correxerunt PP. Gaspar Han et Antolin Abad, OFM, Vol. IX, Madrid 1995: TECNOVIC Arte Gráfico.

\section{Literature}

Alberts, Tara, Conflict and Conversion: Catholicism in Southeast Asia, 1500-1700, Oxford 2013 .

Aldea Vaquero, Quintín (dir.), Diccionario de Historia Eclesiástica de España, 5 vols., Madrid 1972-1987.

Alden, Daurin, The Making of an Enterprise. The Society of Jesus in Portugal, Its Empire, and Beyond. 1540-1750, Stanford 1996.

Anon., "Une pratique liturgique propre à la Chine: Le Tsikin ou Bonnet de messe", in Bulletin Catholique de Pekin 11 (1924): 376-377, 404-406.

Almster, Nadine, Jesuits and Matriarchs: Domestic Worship in Early Modern China, Seattle 2018.

Bastias Saavedra, Manuel, "Jurisdictional Autonomy and the Autonomy of Law: End of Empire and the Functional Differentiation of Law in 19th century Latin America", in Rechtsgeschichte Legal History 26 (2018): 325-337.

Bastias Saavedra, Manuel, "Diversity as Paradox: Legal History and the Blind Spots of Law", in Max Planck Instituted for European Legal History Research Paper Series No. 2020-05 (2018): 1-17.

Benton, Lauren, Law and Colonial Cultures: Legal Regimes in World History, 1400-1900, Cambridge 2001.

Benton, Lauren, Clulow, Adam and Attwood, Bain (ed.), Protection and Empire. A Global History, Cambridge 2018.

Bontnick, François, La lutte autor de la liturgie chinoise aux XVII et XVIII e siècles, Louvain 1962.

Brockey, Liam Mathew, Journey to the East: The Jesuit Mission in China, 1579-1724, Cambridge (MA) 2007 .

Brockey, Liam Mathew, The Visitor: Andre Palmeiro and the Jesuits in Asia, Cambridge (MA) 2014 . 
Brockey, Liam Mathew, "Authority, poverty, and vanity: Jesuit missionaries and the use of silk in early modern East Asia", in Anais de História de Além-Mar 17 (2016): 179-222.

Busquets, Anna, Los tratados históricos, políticos, éticos y religiosos de la monarquía de china (1676) de Domingo Fernández de Navarrete: el texto y sus fuentes (PhD Thesis), Barcelona 2008.

Busquets, Anna, "Más allá de la Querella de los Ritos: el testimonio sobre China de Fernández de Navarrete", in Anuario de la Historia de la Iglesia 24 (2015): 229-250.

Busquets, Anna, "La formación y los recursos intelectuales de los primeros dominicos en China", in Zhang, Xiping, Jingxiang, Wei and González, Inma (coord.), Diego de Pantoja y China. Reflexiones sobre las relaciones históricas entre China y el mundo hispánico. Beijing 2021, 534-564.

Cardim, Pedro et al. (eds.), Polycentric Monarchies: How did Early Modern Spain and Portugal achieve and maintain a Global Economy?, Portland 2012.

Castelnau-L'Estoile, Charlotte, "Une église aux dimensions du monde: expansion du catholicisme et ecclésiologie à l'époque moderne", in Arabeyre, Patrick and Brigitte Basdevant-Gaudemet (dir.), Les clercs et les princes. Doctrines et pratiques de l'autorité ecclésiastique à l'époque moderne, Paris 2013, 323-340.

Chan, Albert, "Late Ming Society and the Jesuit Missionaries", in Ronna, Charles E. and Bonnie B.C. Oh (eds.), East Meets West: The Jesuits in China, 1582-1773, Chicago 1988, 153-172.

Catto, Michela, "Monogamy in polygamy: An interpretation of Chinese marriage by the Society of Jesus", in Ricerche di storia sociale e religiosa 19:1-2 (2019): 7-22.

Collani, Claudia von, "Mission and Matrimony”, in Ku Wei-ying 古偉瀛 (ed.), Missionary approaches and linguistics in mainland China and Taiwan, Leuven 2001, 11-32.

Collani, Claudia von, "The Jesuit Rites Controversy", in Županov, Ines G. (ed.), The Oxford Handbook of the Jesuits, New York 2019, 891-917.

Concilium Sinense, ed. Primum Concilium Sinense anno 1924 a die 14 maii ad diem 12 iunii in ecclesia S. Ignatii de Zi-Ka-Wei celebratum: acta, decretal et normaa, vota, etc., Shanghai 1929.

Cummins, John S. (ed.), The Travels and Controversies of Friar Domingo Navarrete 161886, 2 vols., Cambridge 1962.

Cummins, John S., A Question of Rites. Friar Domingo Navarrete and the Jesuits in China, Cambridge 1993 .

Da Silva, Rômulo, "Casuística nos Trópicos: a pragmática teológico-moral de Francisco Rodrigues na Ásia portuguesa (séculos XVI e XVII)", in Revista da Sociedade e da Cultural 19 (2019): 399-318.

Dehergne, Joseph, Répertoire des Jésuites de Chine de 1552 à 1800, Rome 1973. 
Dipippo Gregory, "The Chinese Sacrificial Hat, and Reflections on Inculturation in China", in New Liturgical Movement. Sacred Liturgy \& Liturgical Arts, 2018. Online: https://www.newliturgicalmovement.org/2018/o8/the-chinese-sacrificial-hat-and. html (last accessed o9.15.2021).

Dowd, Christopher, OP, Rome in Australia: The Papacy and Conflict in the Australian Catholic Missions. 1834-1884, Leiden 2008.

Dudink, Adrian, "The Holy Mass in Seventeenth- and Eighteenth-Century China: Introduction to and Annotated Translation of Yu Misa Goncheng (1721), Manual for Attending Mass", in Noël Golvers and Sara Lievens (eds.), A Lifelong Dedication to the China Mission: Essays Presented in Honor of Father Jeroom Heyndrickx, CICM, on the occasion of his $75^{\text {th }}$ birthday and the 25th anniversary of the F. Verbiest Institute, Leuven 2007, 207-326.

Duve, Thomas, "European Legal History-Concepts, Methods, Challenges", in Duve, Thomas (ed.), Entanglements in Legal History: Conceptual Approaches, Frankfurt am Main 2014, 29-66.

Duve, Thomas, "Pragmatic Normative Literature and the Production of Normative Knowledge in the Early Modern Iberian Empires (16th-17th Centuries)", in Duve, Thomas and Danwerth, Otto (eds.), Knowledge of the Pragmatici. Legal and Moral Theological Literature and the Formation of Early Modern Ibero-America, Leiden 2020, 1-39.

Duve, Thomas, "What is global legal history?", in Comparative Legal History 8:2 (2020): $73^{-115}$.

Elliot, John, The Count-Duke of Olivares: The Statesman in an Age of Decline, New Heaven 1986.

Entenmann, Robert, "Catholic clergy and catechists in Eighteenth-Century Szechwan", in Actes du Vie Colloque International de Sinologie, Chantilly, 1989: Images de la Chine, Le Contexte Occidental de la Sinologie Naissante, Taipei 1995, 389-410.

Entenmann, Robert, "A Mission without missionaries: Chinese Catholic Clergy in Sichuan, 1746-1756", in Yangwen Zheng, Sinicizing Christianity. Studies in Christian Mission 49 (2017): 31-54.

Esquivel, Ricardo, El confinamiento de los misioneros en Guangzhou (1666-1671): Entre las controversias de los ritos chinos y los anticristianismos en China (PhD Thesis), Barcelona 2018.

Faria, Patricia Souza de, "Os concílios provincias de Goa: reflexões sobre o impacto da 'Reforma Tridentina' no centro do império asiático português (1567-16o6)”, in Topoi Revista de História 14:27 (2013). Online: https://doi.org/10.1590/2237-101X014027002 (last accessed 02.02.2021).

Friedrich, Markus, "Jesuit Organization and Legislation: Development and Implementation of a Normative Framework", in Županov, Ines G., The Oxford Handbook of the Jesuits, New York 2019, 23-43. 
Gao Chunming 高春明, Zhongguo fushi mingwukao 中國服飾名物考 [Study of Chinese Dress and Personal Adornment], Shanghai 2001.

Golvers, Noël, “The Canton-Macau Area as a 'lieu de savoir': the Western Missionaries' Detention in the Canton Jesuit Residence $\left(1665^{-1671)}\right.$ and their Written and Editorial Output", in Barreto, Luís Filipe and Wu Zhiliang, International Colloquium Macau: Past and Present, Lisbon 2015, 214-233.

Golvers, Noël, François de Rougemont, SJ, missionary in Changshu (Jiangnan): A study of the 'Account Book' (1674-1676) and the 'Elogium', Leuven 1999.

Golvers, Noël, "New Jesuit testimonies from the far east on the comet of march 1668: The diary of visitor Luis da Gama (Macau) and a letter of Ferdinand Verbiest (Peking)", in Almagest-An international interdisciplinary journal 9:2 (2018): 89-99.

Gong Yingyan 龔纓晏 and Chen Xuejun 陈雪军, Kangxi '‘692 nian kuan rong chi ling' $y u$ Zhejiang 康熙 ‘1692年宽容敕令” 与浙江 [The Edict of Toleration of 1692 by the Emperor Kangxi with Zhejiang], in Huang Aiping 黄爱平 and Huang Xingtao 黄兴涛, Xi xue yu Qing dai wen hua 西学与清代文化 [Western Learning and Qing Dynasty culture], Beijing 2008, 178-182.

González, José María, Historia de las misiones dominicanas de China 1700-1800, 2 vols., Madrid 1964.

Hector, Valerie, "Chinese Bead Curtains, Past and Present", in BEADS: Journal of the Society of Bead Researchers 25 (2013): 40-71.

Hsia, Ronnie Po-chia, "From Buddhist Garb to Literati Silk: Costume and Identity of the Jesuit Missionary", in Paiva, José Pedro, Religious Ceremonials and Images: Power and Social Meaning (1400-1750), Coimbra 2002, 143-154.

Jami, Catherine, "Revisiting the Calendar Case (1664-1669): Science, Religion, and Politics in Early Qing Beijing", in Korean Journal of History of Science 27:2 (2015): 459-477.

Ko, Dorothy, "The Body as Attire: The shifting meanings of footbinding in seventeenthcentury China", in Journal of Women's History 8:4 (1997): 8-27.

Lach, Donald Friederick and Edwin J. Van Kley, Asia in the Making of Europe, vol. 3, Chicago 1993 .

Lamalle, Edmond, "La propagande du P. Nicolas Trigault en faveur des missions de Chine (1616)", in Archivum Historicum Societatis Iesu 9 (1940): 49-120.

Lee, Keekok, Warp and Weft. Chinese Language and Culture, New York 2008.

Levy, Evonne, "Jesuit Identity, Identifiable Jesuits? Jesuit Dress in Theory and in Image", in Oy-Marra, Elisabeth, Remmert, Volker R. and Kristina Müller-Bongard (eds.), Le monde es tune peinture: Jesuitische Identität und die Rolle der Bilder, Berlin 2011, $127-15^{2}$.

López Gay, Jesús, La liturgia en la misión del Japón del siglo XVI, Rome 1970.

Margiotti, Fortunatto, OFM, Il cattolicesimo nello Shansi dalle origini al 1738, Rome 1958. 
Margiotti, Fortunatto, OFM, Alcuni problemi pastorali nella Cina del '70o, Rome 1958.

Marcocci, Giuseppe, A consciência de um império: Portugal e o seu mundo (sécs. $X V$ XVII), Coimbra 2013.

Martínez, Ricardo Eugenio, El confinamiento de los misioneros en Guangzhou (16661671): Entre las controversias de los ritos chinos y los anticristianismos en China ( $\mathrm{PhD}$ Thesis), Barcelona 2018.

Menegon, Eugenio, "Deliver us from Evil: Confession and Salvation in Seventeenthand Eighteenth-Century Chinese Catholicism", in Standaert, Nicolas and Ad Dudink (eds.), Forgive Us Our Sins: Confession in Late Ming and Early Qing China, Nettetal 2006, 9-101

Menegon, Eugenio, "European and Chinese Controversies over Rituals: A SeventeenthCentury Genealogy of Chinese Religion", in Boute, Bruno and Thomas Småberg (eds.), Devising order. Socio-religious Models, Rituals, and the Performativity of Practise, Leiden 2013, 193-222.

Menegon, Eugenio, “The habit that hides the monk': Missionary fashion strategies in late imperial Chinese society and court culture", in Amsler, Nadine et al. (eds.), Catholic Missionaries in Early Modern Asia. Patterns of Localization, London 2020, $30-49$.

Mensaert, George, "L'etablissement de la hiérarchie catholique en Chine de 1705-1785", Archivum Franciscanum Historicum 51 (1958): 369-466.

Metzler, Josef, "Mezzi e modi per l'evangelizzazione dei popoli secondo F.I.", in Pontificia Universitas Urbaniana. Annales CCCLXI (1967-1968), 38-50.

Metzler, Josef, Die Synoden in China, Japan und Korea 1570-1931, Paderborn 1980.

Meynard, Thierry, "Could Chinese Vegetarians be Baptized? Part 1: The Canton Conference and Adrien Grelon SJ's Report of 1668”, Archivum Historicum Societatis Iesu LXXXVII/173 (2018): 75-145.

Meynard, Thierry, "Could Chinese Vegetarians be Baptized? Part 2: The Canton Conference and Prospero Intorcetta SJ's Report of 1668”, Archivum Historicum Societatis Iesu LXXXVIII/176 (2019): 285-341.

Minamiki, George, SJ, The Chinese Rites controversy: From Its Beginning to Modern Times, Chicago 1985.

Motoh, Helena, "Orphan(ed) Scroll: the Case of Contextualizing a Late Qing Object in a Slovenian Museum", in Ming Qing Yanjiu 24:1 (2020): 139-158.

Mungello, David, Curious Land: Jesuit Accommodation and the Origins of Sinology, Stuttgart 1985 .

Noll, Ray R. (ed.), 100 Documents concerning the Chinese Rites Controversy (1645-1941), trans. St. Sure, Donald F., San Francisco 1992.

O’Neill, Charles E., S.I. and Joaquín M. Domínguez, S.I. (dirs.), Diccionario Histórico de la Compañía de Jesús. Biográfico-Temático, 4 vols., Madrid 2001.

Pavone, Sabina, "Riti cinesi”, in Prosperi, Adriano, Dizionario storico dell'Inquisizione, vol. 3 , Pisa 2010, 1324-1327. 
Pavone, Sabina, "Spie, mandarini, bramini: i gesuiti e i loro travestimenti", in Il capitale culturale 7 (2013): 227-247.

Pfister, Louis, Notices biographiques et bibliographiques sur les jésuites de l'ancienne misión de Chine 1552-1773, Shanghai 1932.

Philippi, Dieter, Philippi Collection, 2011. Online: https://philippi-collection.blogspot .com/2011/o7/chinese-jijin-tsikin-tsikim-tsi-kim.html (last accessed o9.15.2021).

Pizzorusso, Giovanni, "Per servitio della Sacra Congregatione de Propaganda Fide: i nunzi apostoloci e le missioni tra centralità romana e Chiesa universale (1622166o)", in Cheiron 30 (1998): 201-227.

Pizzorusso, Giovanni, "Agli antipodi di Babele: Propaganda Fide tra imagine cosmopolita e orizzonti romani (XVII-XIX secolo)", in Fiorani, Luigi and Adriano Prosperi (ed.), Roma, la città del papa. Vita civile e religiosa dal giubileo di Bonifacio VIII al giubileo di papa Wojtyla, Torino 2000, 477-518.

Pizzorusso, Giovanni, "La congrégation 'de Propaganda Fide' à Rome: centre d'accumulation et de production de 'savoirs missionnaires' (XVIIe-début XIXe siècle)", in Castelnau-L'Estoile et al. (eds.), Missions d'évangélisation et circulation des savoirs XVI-XVIII siècles, Madrid 2011.

Pizzorusso, Giovanni, "La Sede apostolica tra Chiesa tridentina e Chiesa missionaria: circolazione delle conosenze e giurisdizione pontificia in una prospettiva globale durante l'età moderna", in Rechtsgeschichte Legal History 20 (2012): 382-385.

Pizzorusso, Giovanni, "La congrégation de la Propagande: une instance centrale pour l'élaboration d'un statu juridique du clergé misionaire", in Arabeyre, Patrick and Brigitte Basdevant-Gaudemet (dir.), Les clercs et les princes. Doctrines et pratiques de l'autorité ecclésiastique à l'époque moderne, Paris 2013, 47-6o.

Prodi, Paolo, Il paradigma tridentino. Un'epoca della storia della Chiesa, Brescia 2019.

Prosperi, Adriano, "Il missionario", in Villarci, Rosario (ed.), L'uomo barocco, Bari 1991, 179-218.,

Raini, Emanuele, "Catechisti e capi laici delle comunità nella storia della chiesa in Cina: prospetto stotico e documenti", in Urbaniana University journal (2019): 97-156.

Rajamanickam, Savarimuthu, "The Goa Conference of 1619", in Indian Church History Review 2:2 (1968): 81-96.

Sanfilippo, Matteo, "Travestimento o tradimento? I missionari cattolici in Cina nei secoli XVI e XVII", in Miscellanea di storia delle esplorazioni 21 (1996): 113-123.

Sanfilippo, Matteo, "L'abito fa il missionario? Scelte di abbigliamento, strategie di adattamento e interventi romani nelle missioni ad haereticos e ad gentes tra XVI e XX secolo", in Mélanges de l'École française de Rome, Italie et Méditerranée 109:2 (1997): 6o1-62o.

Sanfilippo, Matteo, "Adattamento e travestimento: l'abito religioso nelle missioni", in Rocca, Giancarlo (ed.), La sostanza dell'effimero. Gli abiti degli ordini religiosi in Occidente, Rome 2000, 113-118. 
Seah, Audrey, "The 1670 Chinese Missal. A Struggle for Indigenization Amidst the Chinese Rites Controversy", in Clark, Anthony E. (ed.), China's Christianity. From Missionary to Indigenous Church, Leiden 2017, 86-120.

Schutte, Josef Franz, SJ, Valignano's Mission Principles for Japan, St. Louis 1980.

Standaert, Nicolas, "Jesuit Corporate Culture as Shaped by the Chinese", in O'Malley, John et al. (eds.), The Jesuits. Cultures, Sciences, and the Arts 1540-1773, Toronto 1999, $35^{2-263 .}$

Standaert, Nicolas (ed.), Handbook of Christianity in China, vol. 1, Leiden 2001.

Standaert, Nicolas, An Illustrated Life of Christ Presented to the Chinese Emperor: The History of Jincheng shuxiang (1640), Sankt Augustin 2007.

Standaert, Nicolas, The Interweaving of Rituals. Funerals in the cultural exchange between China and Europe, Seattle 2008.

Struve, Lynn A. (ed.), The Qing Formation in World-Historical Time, Cambridge (MA) 2004.

Torres Trimállez, Marina, "Misionares franciscanos y redes locales en Oriente: visiones, identidades y estrategias de evangelización", in Nuevo Mundo Mundos Nuevos (2018). Online: https://journals.openedition.org/nuevomundo/73095 (last accessed 02.02.2O21).

Vareschi, Severini, "Martino Martini S.I. e il decreto del Sant'Ufficio nella Questione dei riti cinesi (1655-56)", in Archivum Historicum Societatis Iesu 63 (1994): 209-26o.

Wakeman, Frederic Jr., The Great Enterprise: The Manchu Reconstruction of Imperial Order in Seventeenth-Century China, 2 vols., Berkeley 1985.

Wilkinson, Endymion Porter, Chinese History: A New Manual, Cambridge (MA) 2013.

Zampol, Linda, "Purple Silk and Black Cotton: Francisco Cabral and the Negotiation of Jesuit Attire in Japan (1570-73)", in Maryks, Robert Alejsander, Exploring Jesuit Distinctiveness: Interdisciplinary Perspectives on Ways of Proceeding Within the Society of Jesus, Boston 2016, 137-155.

Zorkina, Mariana, "Taoist garments in Rituals and Monastic Life", in The Silk Road. Papers from the International Conference organized by Confucius Institute in Sofia (2011): 162-165.

Županov, Ines G. and Pierre-Antoine Fabre (eds.), The Rites Controversies in the Early Modern World, Leiden 2018. 